UNIVERSIDADE DE SÃO PAULO

FCF/FEA/FSP

PROGRAMA DE PÓS-GRADUAÇÃO INTERUNIDADES EM NUTRIÇÃO HUMANA APLICADA - PRONUT

\title{
EFEITOS DA SUPLEMENTAÇÃO DE AMINOÁCIDOS DE CADEIA RAMIFICADA PARA O AUMENTO DE MASSA MUSCULAR E REDUÇÃO DA GORDURA CORPORAL: UMA REVISÃO SISTEMÁTICA
}

\author{
Selma Chiyoko Watanabe \\ Dissertação para obtenção do Título de Mestre \\ Orientadora: Prof. ${ }^{a}$ Assoc. Sandra Maria Lima Ribeiro
}

São Paulo 
UNIVERSIDADE DE SÃO PAULO

FCF/FEA/FSP

PROGRAMA DE PÓS-GRADUAÇÃO INTERUNIDADES EM NUTRIÇÃO HUMANA APLICADA - PRONUT

\title{
EFEITOS DA SUPLEMENTAÇÃO DE AMINOÁCIDOS DE CADEIA RAMIFICADA PARA O AUMENTO DE MASSA MUSCULAR E REDUÇÃO DA GORDURA CORPORAL: UMA REVISÃO SISTEMÁTICA
}

\author{
Selma Chiyoko Watanabe \\ Versão Original \\ Dissertação para obtenção do Título de Mestre \\ Orientadora: Prof. ${ }^{a}$ Assoc. Sandra Maria Lima Ribeiro
}

São Paulo 
Selma Chiyoko Watanabe

\section{EFEITOS DA SUPLEMENTAÇÃO DE AMINOÁCIDOS DE CADEIA RAMIFICADA PARA O AUMENTO DE MASSA MUSCULAR E REDUÇÃO DA GORDURA CORPORAL : UMA}

REVISÃO SISTEMÁTICA Dissertação para obtenção do Título de Mestre

Prof. Dr. orientador/presidente

\begin{tabular}{l}
\hline $1^{\circ}$. examinador \\
\hline $2^{\circ} \cdot$ examinador \\
\hline $3^{\circ} \cdot$ examinador \\
\hline $4^{\circ} \cdot$ examinador
\end{tabular}

São Paulo, de de 2017. 
Ficha Catalográfica

Elaborada pela Divisão de Biblioteca e Documentação do Conjunto das Químicas da USP.

Watanabe, Selma Chiyoko

W324e Efeitos da suplementação de aminoácidos de cadeia ramificada para o aumento de massa muscular e redução da gordura corporal: uma revisão sistemática / Selma Chiyoko Watanabe. -- São Paulo, 2017.

$65 \mathrm{p}$.

Dissertação (mestrado) - Faculdade de Ciências Farmacêuticas da USP. Faculdade de Economia, Administração e Contabilidade da USP. Faculdade de Saúde Pública da USP. Curso Interunidades em Nutrição Humana Aplicada.

Orientador: Ribeiro, Sandra Maria Lima

1. Esporte : Nutrição I. T. II. Ribeiro, Sandra Maria Lima, orientador.

$641.1 \quad \mathrm{CDD}$ 
As pessoas que vencem neste mundo são as que procuram as circunstâncias de que precisam e, quando não as encontram, as criam.

George Bernard Shaw 


\section{DEDICATÓRIA}

Dedico este trabalho a Deus, por me abençoar e me

iluminar nos momentos mais difíceis de minha vida, a quem sou eternamente grata.

A meus Pais, meus fiéis protetores e a quem devo minha eterna gratidão.

Ao meu irmão e minhas irmãs, que sempre me ajudaram nos momentos dificeis.

A meu e esposo e aos meus filhos, principais tesouros que me dão forças nessa caminhada. 


\section{AGRADECIMENTO}

Agradeço à Prof. ${ }^{a}$ Assoc. Sandra Maria Lima Ribeiro, pela confiança depositada em mim, pelo incentivo, pelas orientações e conhecimentos transmitidos, pela compreensão nos momentos difíceis e principalmente pela amizade gerada nessa caminhada.

À Prof. ${ }^{a}$ Dra. Denise Cavallini Cyrillo por ter me recebido de braços abertos e me acolhido no início deste trabalho.

À banca examinadora pela disponibilidade e contribuição com este trabalho.

À todos os professores e funcionários que sempre foram atenciosos e prestativos.

Agradeço em especial, às minhas amigas Amparo, Eliana, Kristy e Shirley, que sempre me apoiaram, me incentivaram com seus conselhos, me socorreram em vários momentos que precisei, e principalmente pelos bons momentos que tivemos.

À todas as pessoas que direta ou indiretamente contribuíram para o término desta dissertação. 


\section{RESUMO}

WATANABE, S.C. Efeitos da suplementação de aminoácidos de cadeia ramificada para o aumento de massa muscular e redução da gordura corporal: uma revisão sistemática. 2017. 68f. Dissertação (Mestrado) - FCF/FEA/FSP, Universidade de São Paulo, 2017.

A busca pelo aumento da força muscular, em paralelo à diminuição da gordura corporal e melhora do rendimento esportivo, tem levado muitas pessoas ao uso de suplementos de proteínas e/ou aminoácidos, associados com a prática de exercícios físicos. Dentre os inúmeros suplementos de proteínas ou aminoácidos disponíveis no mercado, têm merecido destaque nas últimas décadas os aminoácidos essenciais de cadeia ramificada, também chamados de branched chain amino acids (BCAA's). O suplemento chamado de BCAA é uma combinação de três aminoácidos essenciais - L-Leucina, L-Valina e L-Isoleucina. As alegações feitas a esses aminoácidos giram em torno de seus efeitos sobre a síntese proteica no músculo esquelético, diminuição dos danos musculares, redução da gordura corporal e melhora do desempenho físico. O presente estudo teve como objetivo realizar uma revisão sistemática de estudos clínicos na utilização desses aminoácidos no intuito de aumentar a massa muscular, reduzir a gordura corporal e aumentar o rendimento esportivo, avaliando os resultados obtidos e que comprovem seu uso e segurança. A busca dos artigos nas bases de dados resultou em 7502 artigos. Seguindo todos os critérios de inclusão e exclusão, 11 artigos foram selecionados para esta revisão sistemática. A performance foi avaliada em 6 artigos. A massa muscular foi avaliada em 5. Não foram encontrados artigos visando a redução de gordura corporal. A dose de BCAA utilizada foi de $1,2 \mathrm{~g}$ até $10 \mathrm{~g}$ e os estudos ministraram os suplementos na forma de pó, cápsulas e infusão. A melhor relação entre leucina, valina e isoleucina foi de 2:1:1, respectivamente. Considerando que o número de estudos com resultados benéficos praticamente se iguala ao de resultados negativos, mais estudos são necessários para que se comprove os reais benefícios do uso de BCAA como suplemento estratégico para aumentar a massa muscular, reduzir a gordura corporal e aumentar o rendimento esportivo.

Palavras-chave: aminoácidos de cadeia ramificada, BCAA, exercício, adiposidade, massa muscular, força muscular. 


\begin{abstract}
WATANABE, S.C. Effects of branched chain amino acid supplementation for increasing muscle mass and reducing body fat: a systematic review. 2017. 68f. Dissertation (Master's degree) - FCF/FEA/FSP, Universidade de São Paulo, 2017.

The search for increased muscle strength, in parallel to decreased in body fat and improved sports performance has led many people to use protein and/or amino acid supplements associated with the practice of physical exercises. Among the numerous supplements of proteins or amino acids available in the market, the branched chain amino acids (BCAA's) have deserved prominence in the last decades. The supplement called BCAA is a combination of three essential amino acids - L-Leucine, L-Valine and L-Isoleucine. The claims made to these amino acids revolve around their effects on protein synthesis in skeletal muscle, decreased muscle damage, reduced body fat and improved physical performance. The present study aimed to perform a systematic review of clinical studies in the use of these amino acids in order to increase muscle mass, reduce body fat and increase sports performance, evaluating the results obtained and proving its use and safety. Search for articles in databases resulted in 7502 articles. Following all the exclusion criteria, 11 articles were selected for the present systematic review. The performance was evaluated in 7 articles. The muscle mass was evaluated in 4 . The used dose of BCAA ranged from $1.2 \mathrm{~g}$ to $10 \mathrm{~g}$ and studies have given supplements in the form of powder, capsules and infusion. The best ratio of leucine, valine and isoleucine was $2: 1: 1$, respectively. Considering that the number of studies with beneficial results almost equals that of negative results, more studies are needed to prove the real benefits of using BCAAs as a strategic supplement to increase muscle mass, reduce body fat and increase sports performance.
\end{abstract}

Keywords: branched chain amino acids, BCAA, exercise, adiposity, muscle mass, muscle strength. 


\section{LISTA DE FIGURAS}

Figura 1 - Papéis dos aminoácidos na nutrição e homeostase do organismo.............. 17

Figura 2 - Reações do catabolismo do BCAA................................................... 19

Figura 3 - Capacidade do organismo de catabolizar o BCAA................................ 20

Figura 4 - Esquema proposto para a ativação da sinalização da síntese proteica........ 21

Figura 5 - Fluxograma do estudo............................................................... 31 


\section{LISTA DE QUADROS E TABELAS}

Quadro 1 - $\quad$ Plano geral para construção das combinações de busca......................... 26

Tabela 1 - $\quad$ Sumário dos estudos incluídos segundo os critérios de inclusão............. 32

Tabela 2 - $\quad$ Sumário dos estudos excluídos segundo os critérios de exclusão............ 37

Tabela 3 - $\quad$ Sumário dos estudos excluídos segundo os critérios de exclusão............ 37

Tabela 4 - $\quad$ Sumário da Avaliação do risco de viés............................................... 38

Tabela 5 - $\quad$ Sumário da coleta de dados do estudo................................................ 43

Tabela 6 - Resultados obtidos a partir das publicações selecionadas para a

presente revisão sistemática....................................................... 52 


\section{LISTA DE ABREVIATURAS}

\begin{tabular}{|c|c|}
\hline Acetil-CoA & Acetil-coenzima A \\
\hline Acil-CoA & Acil-coenzima A \\
\hline ADP & Adenosina difosfato \\
\hline ATP & Adenosina trifosfato \\
\hline Akt & Proteína quinase B \\
\hline BCAA & Branched Chain Amino Acid \\
\hline BIA & Bioimpedância elétrica \\
\hline CCTR & Registro Cochrane de Ensaios Clínicos Controlados \\
\hline $\mathrm{CHO}$ & Carboidrato \\
\hline CK & Creatina quinase \\
\hline $\mathrm{CO} 2$ & Dióxido de carbono \\
\hline $\mathrm{CoA}$ & Coenzima A \\
\hline $\mathrm{CoA}-\mathrm{SH}$ & Coenzima A reduzida \\
\hline DNA & Ácido desoxirribonucleico \\
\hline DOMS & Dor muscular retardada \\
\hline DXA & Densitometria por emissão de raios x de dupla energia \\
\hline eIF2B & Fator de iniciação eucariótico \\
\hline HIV & Vírus da Imunodeficiência Humana \\
\hline IB-CoA & Isobutiril-Coenzima A \\
\hline IRS-1 & Substrato de receptor de insulina \\
\hline IV-CoA & Isovaleril-Coenzima A \\
\hline KIV & $\alpha$-cetoisovalerato \\
\hline KIC & $\alpha$-cetoisocaproato \\
\hline KMV & $\alpha$-ceto- $\beta$ metilvalerato \\
\hline MAFbx & Muscle atrophy F-box \\
\hline MAPR & Taxa máxima de produção de ATP mitocondrial \\
\hline MB-CoA & $\alpha$-metilbutiril-CoA \\
\hline MPS & Síntese proteica muscular \\
\hline mRNA & Ácido ribonucleico mensageiro \\
\hline
\end{tabular}


MtDNA Ácido desoxirribonucleico mitocondrial

mTOR Mamalian Target of Rapamycin

MuRF-1 Muscle RING-finger protein-1 ou atrogina

MVC Contração voluntária máxima

NAD+ Nicotinamida adenina dinucleotídio oxidada

$\mathrm{NADH} \quad$ Nicotinamida adenina dinucleotídio reduzida

$\mathrm{Pi} \quad$ Fosfato inorgânico

P70S6k Proteína quinase ribossomal S6 70

R-CoA Derivados da coenzima A

RER Relação de troca respiratória

RNA Ácido ribonucleico

RPE Taxa do esforço percebido

rpS6 Proteína ribossomal S6

SPD Sports drink

Succinil-CoA Succinil-coenzima A

TCA Ciclo do ácido tricarboxílico

VJ Salto vertical

VO2 Volume de oxigênio

4E-BP1 Fator de iniciação eucariótico 4E 


\section{SUMÁRIO}

1. INTRODUÇÃO

1.1 Consumo e informações comerciais sobre suplementos nutricionais.................... 15

1.2 Conceitos sobre o metabolismo de proteínas, com destaque para os BCAA....... 16

2. OBJETIVO

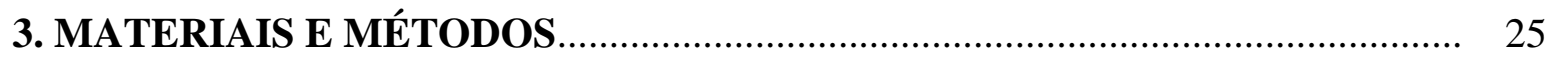

3.1 Critérios de inclusão..................................................................................... 27

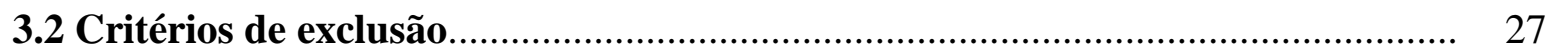

4. RESULTADOS

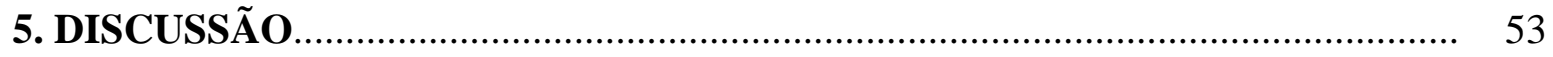

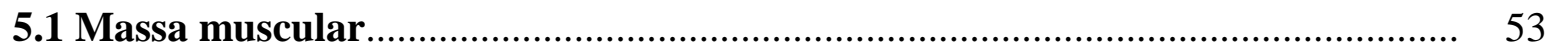

5.2 Performance

6. CONCLUSÕES E RECOMENDAÇÕES .............................................................. 60

REFERÊNCIAS BIBLIOGRÁFICAS..................................................................... 61 


\section{INTRODUÇÃO}

\subsection{Consumo e informações comerciais sobre suplementos nutricionais}

O consumo de suplementos nutricionais pela população mundial tem aumentado muito nos últimos anos. Segundo dados da Euromonitor, o mercado global de suplementos em 2010, foi de aproximadamente U\$ 121 bilhões; em 2011 de U\$ 153bilhões; em 2012 de U\$ 174 bilhões; em 2013 de U\$ 190 bilhões; em 2014 de U\$ 350 bilhões e em 2015 de U\$ 400 bilhões.

O percentual de consumo no mercado global foi de: Ásia-Pacífico (44,2\%), América do Norte (32,6\%), Europa Ocidental (14,4\%), América Latina (3,1\%), Europa Oriental (2,7\%). Ainda segundo a pesquisa da Euromonitor, em 2010 o Brasil era o segundo maior mercado da América Latina (México, em primeiro) e crescia em média 25\% ao ano. Nos EUA, 57\% da população faz uso desses produtos, enquanto que no Brasil esse percentual está em 2\%. Dados da ABENUTRI (Associação Brasileira de Empresas de Produtos Naturais) mostram que o número de lojas de suplementos e de produtos Naturais no Brasil, passou de 323, em 2009, para 1413 em 2012 e manteve a média de aberturas de 1,1 mil novas lojas por ano (ABENUTRI, 2015).

Esse grande aumento no consumo pode atingir níveis relacionados a riscos à saúde. Existem diversas fontes de informações, com diferentes níveis de qualidade, atribuídos a diferentes suplementos, e dado o nível de educação da população em geral, essas informações podem gerar controvérsias (HALLAK et al, 2007).

A busca pelo aumento da força muscular em paralelo à diminuição da gordura corporal e melhora da performance esportiva tem levado muitas pessoas ao uso de suplementos de proteínas e/ou aminoácidos, associados com a prática de exercícios físicos

para obtenção do corpo perfeito e para uma melhor qualidade de vida (HIRSCHBRUCH et al, 2008).

Estudos com suplementos de aminoácidos têm sido realizados há vários anos, e muitos têm mostrado eficácia com essa suplementação, enquanto que, em outros, os resultados são inconclusivos (NOGIEC et al., 2013). 


\subsection{Conceitos sobre o metabolismo de proteínas, com destaque para os BCAA}

As proteínas são macromoléculas formadas por unidades menores, ou unidades fundamentais, os aminoácidos, unidos por meio de ligações peptídicas. Existem 20 aminoácidos que se combinam de diferentes formas para compor as proteínas do corpo humano. Estes aminoácidos diferem em sua estrutura química, e podem ser divididos em sulfurados, aromáticos, básicos, ácidos e aminoácidos de cadeia ramificada.

As proteínas são específicas de cada ser vivo, e por isto, quando são ingeridas pela dieta, necessitam ser digeridas até aminoácidos, para que sejam reorganizados de forma a comporem as proteínas próprias do corpo humano. A digestão das proteínas origina aminoácidos, dipeptídeos e tripeptídeos. Os peptídeos e aminoácidos absorvidos são transportados ao fígado através da veia porta, para liberação na circulação geral e posteriormente captados pelos tecidos (MAHAN et al, 2002).

Ainda, de acordo com sua essencialidade para o organismo, os aminoácidos podem ser divididos em essenciais e não essenciais, sendo que os primeiros necessitam obrigatoriamente serem ingeridos, pois o organismo não consegue sintetizar. Já os

aminoácidos não essenciais podem ser sintetizados no fígado, a partir de processos de transaminação de outros aminoácidos (WU, 2010).

Dentre várias funções atribuídas aos aminoácidos no organismo, cabe destacar o papel estrutural, ou seja, eles compõem a massa corporal total. Das proteínas corporais, $98 \%$ compõem a massa muscular, e somente $2 \%$ estão na forma de proteínas circulantes. Os aminoácidos têm ainda papel fundamental na regulação de um grande número de processos celulares, não são só sinalizadores moleculares das células, mas também regulam a expressão gênica e a cascata de fosforilação relacionada à síntese de proteínas (WU, 2009). Atuam como chaves nas vias metabólicas necessárias para garantir a saúde, sobrevivência, manutenção, crescimento e a reprodução conforme mostrado na Figura 1. Determinadas condições nutricionais e algumas formas de estresse podem afetar a absorção e metabolização dos mesmos (BRUHAT et al., 2009). 


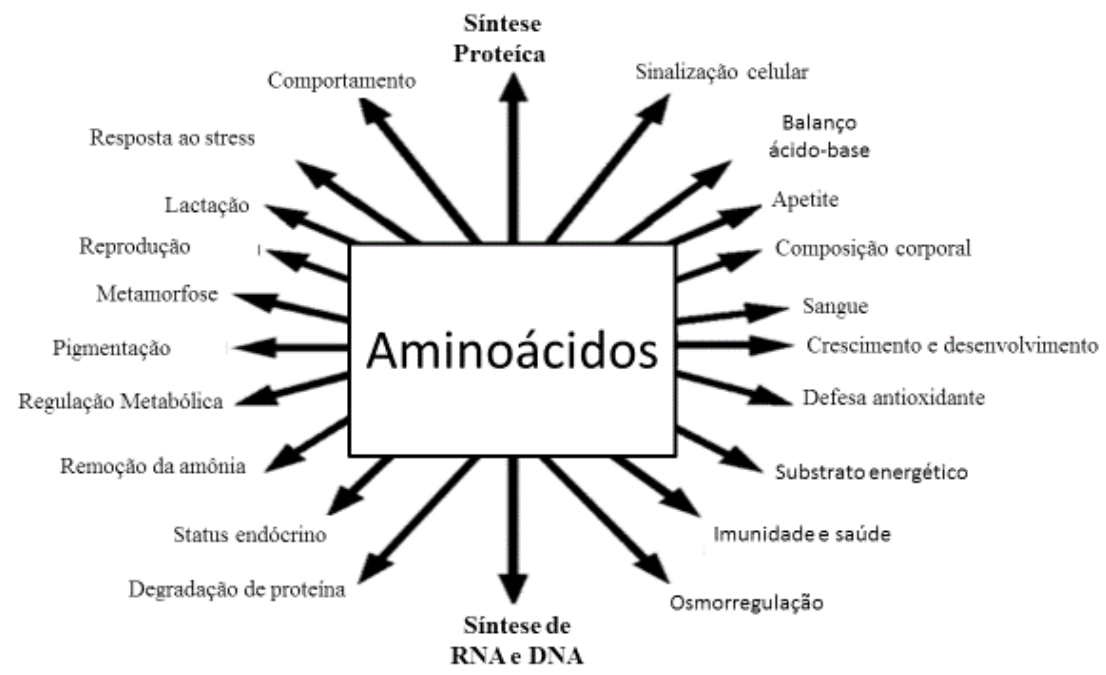

Figura 1. Papéis dos aminoácidos na nutrição e homeostase de todo o organismo.

Fonte: Adaptado de Wu (2010).

A falta de algum desses aminoácidos, pode prejudicar a síntese de proteínas e também a homeostase de todo o organismo. Há muito tempo vem sendo investigado se o uso de estratégias nutricionais, tais como o uso de suplementos com aminoácidos específicos, é capaz de contribuir com processos como crescimento, reprodução e saúde (WU, 2010). Dentre os inúmeros suplementos de aminoácidos disponíveis no mercado, têm merecido destaque, nas últimas décadas, as qualidades nutricionais dos aminoácidos essenciais (BCAA`s), também chamados de branched chain amino acids ou aminoácidos de cadeia ramificada. O chamado genericamente de BCAA é uma combinação de três aminoácidos essenciais: L-Leucina, L-Valina e L-Isoleucina. Esses aminoácidos possuem diversos papéis fisiológicos e metabólicos. Eles são oxidados principalmente no músculo esquelético, enquanto os outros aminoácidos são oxidados preferencialmente no fígado. $\mathrm{O}$ organismo possui um sistema enzimático bastante eficiente para a degradação do BCAA, por isso, quando ingeridos em excesso, são rapidamente eliminados. Alguns intermediários formados de sua degradação, principalmente os $\alpha$-cetoácidos de cadeia ramificada, em altas concentrações, podem vir a ser tóxicos. Assim, a eliminação do excesso de BCAA's é muito importante para a manutenção das condições normais do organismo (SHIMOMURA et al., 2004).

O metabolismo dos BCAA's apresenta características próprias. Uma das características é que seu catabolismo envolve dois passos comuns, a primeira reação é uma 
transaminação reversível do BCAA para produzir $\alpha$-cetoácidos de cadeia ramificada, catabolizado pela aminotransferase de aminoácidos de cadeia ramificada, os $\alpha$-cetoácidos podem ser precursores da síntese de glutamina e de alanina, a partir da conversão do $\alpha$ cetoglutarato em glutamato. A segunda reação é uma oxidação irreversível de descarboxilação dos $\alpha$-cetoácidos de cadeia ramificada para formar compostos da coenzima A (CoA), que são catabolizados pelo complexo enzimático desidrogenase de cetoácidos de cadeia ramificada conforme mostrado na Figura 2. A regulação do complexo enzimático desidrogenase de cetoácidos de cadeia ramificada é feita pela sua fosforilação e desfosforilação, sendo que a desidrogenase de cetoácidos de cadeia ramificada quinase, é responsável pela fosforilação e consequente inativação do complexo enzimático, e a desidrogenase de cetoácidos de cadeia ramificada fosfatase, é responsável por sua reativação, quando de sua desfosforilação (SHIMOMURA et al, 2004). Há evidências que a desidrogenase de cetoácidos de cadeia ramificada quinase, é considerada a chave que regula a atividade do complexo. Por isso essa reação é fator limitante do catabolismo do BCAA. Ela é inibida pelos $\alpha$-cetoácidos, mais predominantemente pelo $\alpha$-cetoisocaproato (produzido pela transaminação da leucina), que regula a disponibilidade de BCAA, dependendo do excesso ou escassez do mesmo. (BROSNAN et al, 2006). Aumento na atividade do complexo enzimático desidrogenase de cetoácidos de cadeia ramificada quinase, pode causar degradações irreversíveis nos BCAAs, já uma diminuição do $\alpha$ cetoisocaproato, devido a um déficit de leucina ou uma rápida síntese proteica, pode levar a uma inibição da atividade da desidrogenase de cetoácidos de cadeia ramificada quinase, resultando na inativação do complexo, preservando o BCAA para síntese proteica (HARRIS et al, 2001). Após a ação do complexo enzimático desidrogenase de cetoácidos de cadeia ramificada, ocorre a formação dos derivados acil-CoA de cadeia ramificada e NADH. A oxidação dos acil-CoA de cadeia ramificada é realizada por duas desidrogenases e a partir dessa etapa, os aminoácidos do BCAA, seguem vias catabólicas diferentes. A leucina é cetogênica e forma o acetil-coA e acetoacetato, a valina é glicogênica, sendo utilizada no ciclo do ácido tricarboxílico como succinil-CoA. A isoleucina e valina são metabolizadas para succinato. Todos esses metabólitos do BCAA podem ser utilizados pelos tecidos (HUTSON et al., 2005). 


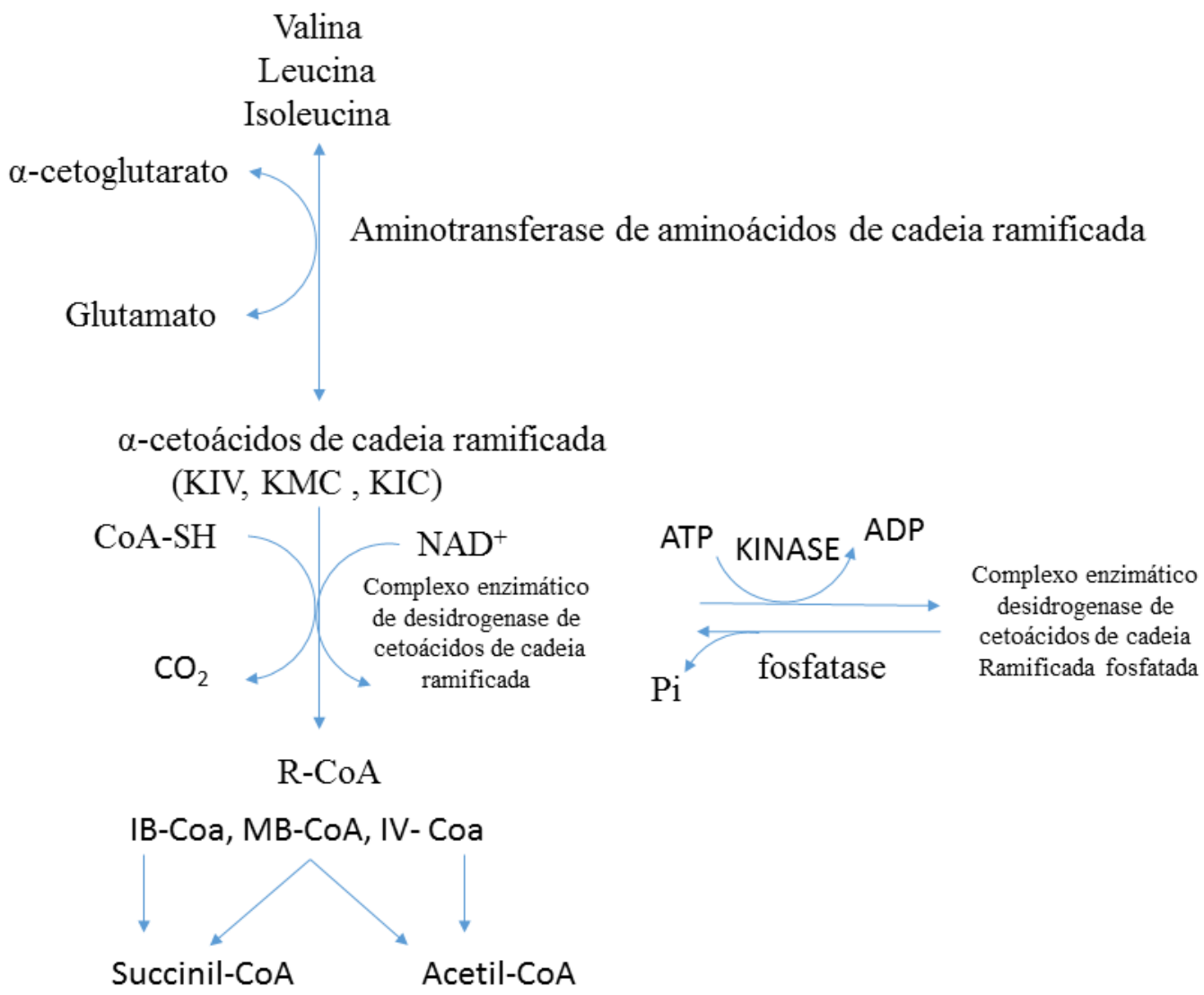

Figura 2. Reações do catabolismo do BCAA. KIV, $\alpha$-cetoisovalerato; KMV, $\alpha$-ceto- $\beta$ metilvalerato; KIC, $\alpha$ cetoisocaproato; CoA-SH, coenzima A reduzida; IB-Coa, isobutiril-CoA; MB-CoA, $\alpha$-metilbutiril-CoA; IVCoA, isovaleril-CoA.

Fonte: Adaptado de Shimomura et al.. (2004).

Outra característica do metabolismo do BCAA é a compartimentalização das isoenzimas, aminotransferase de aminoácidos de cadeia ramificada e a desidrogenase de cetoácidos de cadeia ramificada nos órgãos e tecidos. Por isso, a capacidade de catabolização do BCAA nos tecidos do organismo difere muito, conforme mostrado na Figura 3. O cálculo dessa capacidade foi feito multiplicando-se as atividades da aminotransferase de aminoácidos de cadeia ramificada e a desidrogenase de cetoácidos de cadeia ramificada de diferentes tecidos, pela massa desses tecidos em pessoas com $70 \mathrm{~kg}$. Assim, podemos verificar porque quase metade da capacidade do metabolismo do BCAA ocorre no músculo esquelético, em menor escala no tecido adiposo e bem menos ainda no fígado (BROSNAN et al.., 2006). 

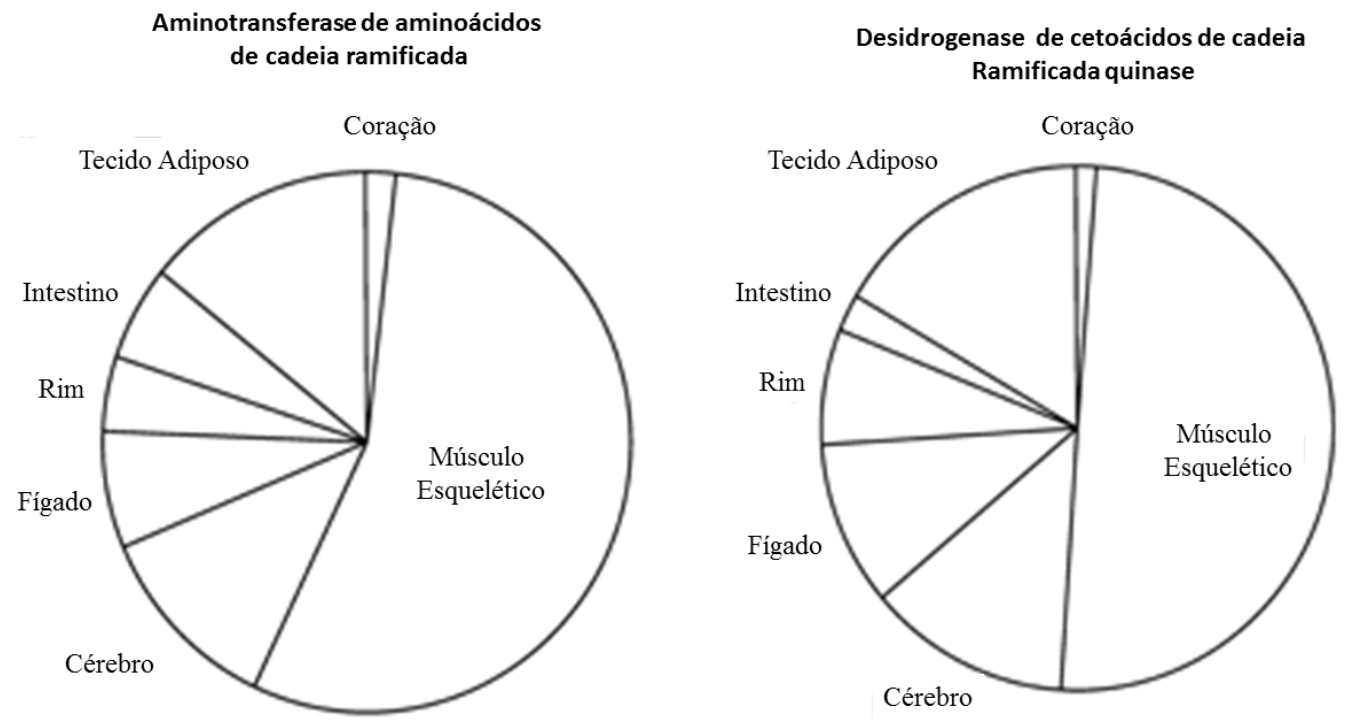

Figura 3. Capacidade do organismo de catabolizar o BCAA. Distribuição nos tecidos humanos de aminotransferase de aminoácidos de cadeia ramificada e de desidrogenase de cetoácidos de cadeia ramificada. Fonte: Adaptado de Brosnan et al. (2006).

Observa-se que a disponibilidade de aminoácidos no plasma é a chave para promover o anabolismo de proteínas musculares, regulando a taxa de síntese e degradação proteica (KATSANOS et al., 2008; WOLFE, 2000). Existem evidências que a combinação de exercícios resistidos e uma ingestão aumentada de proteínas ou aminoácidos, desencadeiam ativação sinérgica de uma proteína quinase chamada de alvo de rapamicina mTOR (mamalian Target of Rapamycin), da enzima p70S6 quinase (p70S6K), do fator de iniciação eucariótico 4E-BP1 e do fator de iniciação eucariótico eIF2B. A ativação p70S6 quinase e subsequente fosforilação da proteína ribossomal S6 está associada com o aumento da translação de mRNAs específicos, que irão codificar proteínas ribossomais (Figura 4). Essas enzimas são responsáveis para o início da tradução de proteínas (BLOMSTRAND et al., 2006). O mTOR tem um papel importante durante o processo de hipertrofia das células esqueléticas. Efeitos estimulatórios da administração oral de BCAA, particularmente de leucina sobre o mTOR, p70S6K e os fatores de iniciação eucarióticos têm sido demonstrados em estudos com ratos, mas a leucina não estimulou a via da insulina, incluindo a proteína quinase B (Akt) nos músculos dos mesmos (Kimball \& Jeffferson, 2004). 


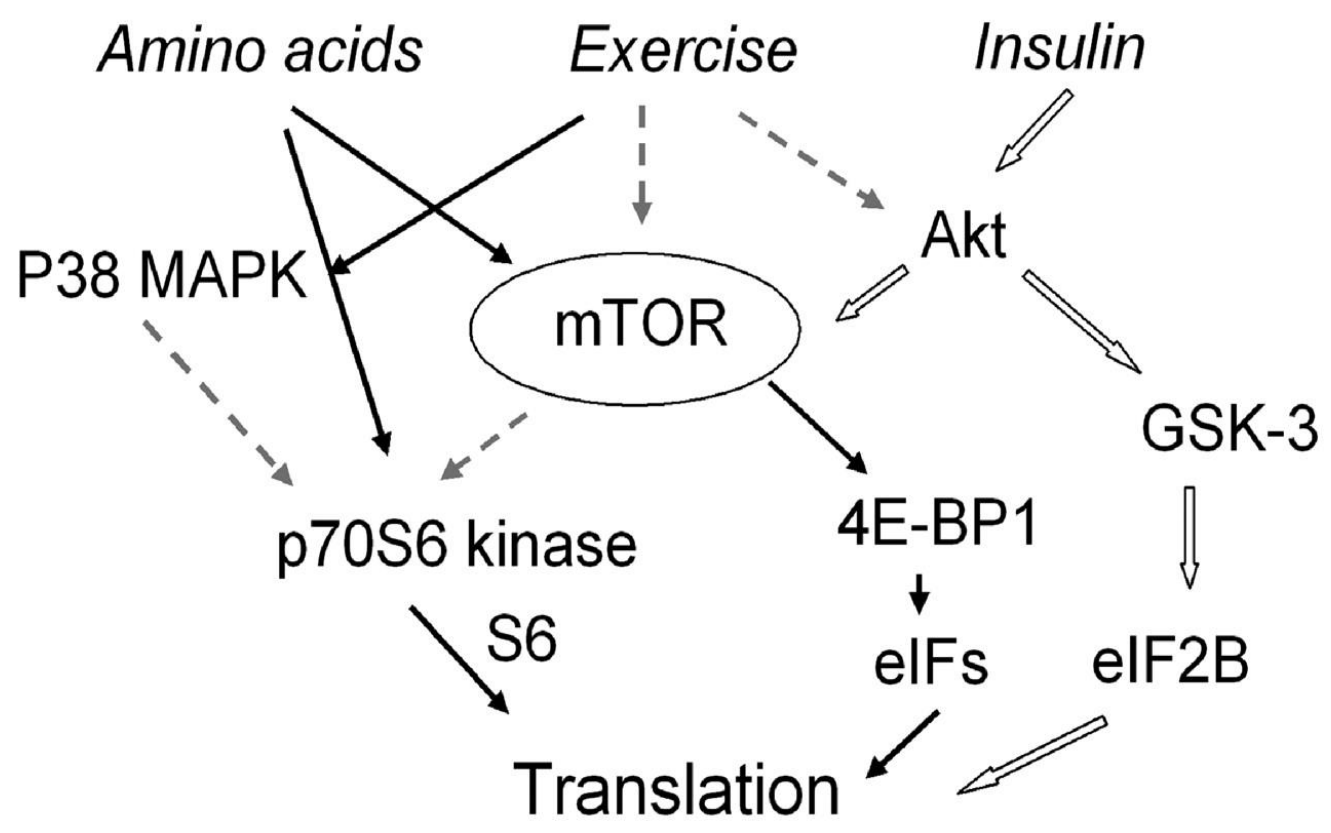

Figura 4. Esquema proposto para a ativação da sinalização da síntese proteica por aminoácidos/BCAA e exercício de resistência no músculo humano. Flechas sólidas, demonstram efeito; flechas tracejadas, possíveis efeitos; flechas abertas, efeito da insulina.

Fonte: Adaptado de Kimball SR, Jefferson LS (2004).

Estudos também têm demostrado a importância dos aminoácidos de cadeia ramificada, particularmente a leucina, que atua no metabolismo das proteínas, estimulando a síntese proteica, e diminuindo o catabolismo proteico muscular (BLOMSTRAND et al., 2006; PASIAKOS, 2012; CHURCHWARD-VENNE et al., 2012).

Além dos possíveis efeitos ergogênicos dos aminoácidos de cadeia ramificada no metabolismo muscular, outros têm sido sugeridos: retardar a ocorrência de fadiga central (NEWSHOLME \& BLOMSTRAND, 2006), aumentar o rendimento esportivo (MADSEN et a.1, 1996; KNECHTLE et al.., 2011), poupar os estoques de glicogênio muscular e aumentar os níveis plasmáticos de glutamina após o exercício intenso (BLOMSTRAND \& SALTIN, 2001) e reduzir a gordura corporal (QIN et al.., 2010).

No cérebro, o BCAA pode ser doador de nitrogênio para a síntese de neurotransmissores (HUTSON et al.., 2005). Para ser transportado para o cérebro, o BCAA compete pelo mesmo transportador de outros aminoácidos. O BCAA possui uma relação inversa com o triptofano no cérebro. O triptofano é precursor da serotonina, que atua como 
um mediador da fadiga central. Partindo dessa suposição, a suplementação com BCAA, pode prevenir a fadiga central durante exercícios prolongados (MONIRUJJAMAN et al.., 2014).

Evidências sugerem que o tecido adiposo é capaz de metabolizar quantidades significativas de BCAA, devido ao percentual de concentração da desidrogenase de cetoácidos de cadeia ramificada no mesmo. Estudos relatam que taxas elevadas de BCAA em obesos podem ser causadas pela alteração da expressão das enzimas catabólicas do mesmo. Estados de resistência à insulina relacionados ao BCAA também geram grande interesse por parte dos pesquisadores (HERMAM et al., 2010). Há evidências que dietas com alta concentração de proteínas e redução de carboidratos são benéficas para perda de peso e aumento da diminuição da gordura corporal porque a leucina pode interagir com a via de sinalização da insulina e parece regular a oxidação da glicose pelo músculo esquelético, via ciclo da alanina-glicose. Recentemente, verificou-se que um aumento na disponibilidade de BCAA (leucina) no hipotálamo pode ser um potente sinal para redução da ingestão de alimentos. A suplementação com uma dieta rica em gorduras associada com BCAA reduziu a ingestão de alimentos e o peso corporal. Muitos estudos ainda apresentam controvérsias que precisam ser esclarecidas (WANG et al.., 2013). Assim, a prática de suplementação nutricional em especial de proteínas e aminoácidos, tem recebido suporte de pesquisas científicas (PASIAKOS, 2012).

Considerando todos os efeitos propostos para a suplementação de BCAA, tem ocorrido um aumento no consumo desses suplementos. Os suplementos de BCAA são oferecidos no mercado, na forma de cápsulas e em pó. A recomendação estabelecida pela Portaria 222 de 24 de março de 1998, da ANVISA é de que a formulação desses aminoácidos deve fornecer a ingestão diária de até 100\% das necessidades diárias de cada aminoácido; sendo que as necessidades diárias estabelecidas são de $10 \mathrm{mg} / \mathrm{kg} / \mathrm{dia}$ de isoleucina, $14 \mathrm{mg} / \mathrm{kg} /$ dia de leucina e de $10 \mathrm{mg} / \mathrm{kg} / \mathrm{dia}$ de valina. Vários estudos utilizaram a suplementação de BCAA com dosagens que variam de 1,2 g até 10g (VERHOEVEN et al., 2009; PELTIER et al., 2011; SPILLANE et al., 2012). Considerando as diferenças de dosagens encontradas em vários estudos, há a necessidade de se estabelecer as doses de BCAA que realmente sejam eficazes, seguras e não gerem efeitos tóxicos. 
Uma busca prévia nas bases MEDLINE e LILACS não revelou nenhuma revisão sistemática sobre o uso isolado, em estudos clínicos com humanos, de BCAA`s no aumento da massa muscular, na redução da gordura corporal e no aumento do rendimento físico. No entanto, existe um grande número de pesquisas, principalmente com modelos em animais não humanos, investigando a utilização desse suplemento. Assim, as seguintes questões são levantadas no presente estudo:

1. Existem estudos clínicos que avaliem os BCAA`s para o consumo humano?

2. Quais são os reais efeitos benéficos, no que diz respeito à composição corporal e síntese de proteínas, com a suplementação de BCAA`s?

Desse modo, a revisão sistemática da literatura possibilita avaliar de maneira crítica todos os estudos já publicados sobre o tema, sintetizar e mapear de maneira reproduzível as informações para melhor tomada de decisão e servir de auxílio para futuras pesquisas. 


\section{OBJETIVO}

Identificar, por meio de revisão sistemática, estudos que tenham utilizado diferentes formas de $B C A A$ `s com o objetivo de aumentar ou manter a massa muscular esquelética, de reduzir gordura corporal ou de melhorar marcadores de rendimento esportivo que sejam associados com a síntese de proteínas. 


\section{MATERIAIS E MÉTODOS}

O presente estudo caracteriza-se por uma revisão sistemática, que é uma técnica científica objetiva, eficiente e reproduzível, que permite extrapolar achados de estudos independentes, avaliar a consistência de cada um deles e explicar as possíveis inconsistências e conflitos. Além disso, é uma técnica que aumenta a acurácia dos resultados, melhorando a precisão das estimativas de efeito de uma determinada intervenção clínica (MULROW, 1994). O presente estudo foi realizado tomando como base algumas referências sobre o assunto, a saber: The PRISMA Statement for reporting systematic reviews and meta-analyses (LIBERATI et al., 2009); a colaboração Cochrane (THE COCHRANE COLABORATION, 2008), e a biblioteca virtual da Escola Paulista de Medicina (http://www.virtual.epm.br/). Para tornar o presente projeto didático, os métodos que foram seguidos para a realização do estudo estão descritos de acordo com o estabelecido pelo The PRISMA Statement for reporting systematic reviews and metaanalyses (LIBERATI et al., 2009). Portanto, descreveremos os métodos dividindo-os em 9 etapas.

- $1^{a}$ etapa: Localização e seleção dos estudos primários:

As fontes para identificação dos estudos primários foram as seguintes:

a) Bases de dados eletrônicas: i) EMBASE (Excerpta Medica Database); ii) Registro Cochrane de Ensaios Clínicos Controlados (CCTR); iii) LILACS (Literatura Latino - Americana e do Caribe em Ciências da Saúde; iv) MEDLINE; v) Web of Science, também foram consultados sítios específicos da Internet relacionados à medicina esportiva, e que agregam a divulgação de estudos científicos a saber: American College of Sports Medicine, European College of Sports.

b) Grupo Cochrane de revisão: a partir de seu sítio eletrônico;

1. Listas de referências dos estudos selecionados foram em todos os estudos incluídos;

2. Comunicação pessoal foi feita por meio do envio de correspondência (correio postal ou eletrônico) aos autores dos estudos incluídos;

3. Busca manual foi feita em publicações regionais não indexadas, anais de congressos, teses e dissertações entre outras. A identificação dos estudos não 
publicados teve como objetivo evitar o viés de publicação, uma vez que estudos que não demonstram benefícios de uma intervenção estão mais propensos a não serem publicados (SOUZA \& RIBEIRO, 2009).

Período de coleta de dados: foram incluídas nos estudos, pesquisas publicadas no período de janeiro de 2009 até 2015.

Idiomas para a busca de pesquisas: português, inglês, qualquer outro idioma foi excluído.

Palavras chaves que foram utilizadas na busca: as pesquisas foram identificadas utilizando as palavras chaves incluídas no título e no resumo dos textos. Foi construída uma tabela a partir do cruzamento das diferentes possibilidades com os três grupos de termos. Os termos foram derivados das perguntas formuladas na introdução do presente estudo. O plano geral para construção das combinações de busca descrita no Quadro 1.

Quadro 1. Plano geral para construção das combinações de busca

\begin{tabular}{|l|l|l|}
\hline \multicolumn{1}{|c|}{ Resultados } & Intervenções & Tipo de Estudo \\
\hline $\begin{array}{l}\text { \# Massa muscular livre de } \\
\text { gordura }\end{array}$ & \# Exercício & \# Estudos randomizados duplos \\
\#Massa magra & \# BCAA \\
\# Massa muscular & \# Suplemento \\
\# Performance & \# Suplementação & \# Ensaios simples cegos \\
\#Adiposidade & \# Aminoácidos de cadeia \\
\# Hipertrofia & ramificada & \# Estudo “open label”, \\
\#Anabolismo & \# Aminoácidos essenciais \\
\#Balanço proteico & \# Leucina & \\
\#Balanço de nitrogênio &
\end{tabular}

\subsection{Critérios de Inclusão}

a) Estudos cujos objetivos tenham sido avaliar o efeito dos BCAA`s isolados ou em combinação com outros suplementos não proteícos, no aumento ou manutenção da massa muscular, e ou redução de gordura e ou melhora de marcadores de 
rendimento (que fossem associados à síntese proteica), em indivíduos de várias faixas etárias submetidos ou não ao exercício físico;

b) Tipos de Estudos: foram incluídos os ensaios clínicos cegos, duplo-cegos ou open label;

c) Quanto à situação clínica dos indivíduos do estudo: os estudos contemplaram indivíduos saudáveis, treinados ou não treinados, de todas as faixas etárias e de ambos os sexos, sem histórico de doenças relacionadas ao catabolismo muscular;

d) Quanto à intervenção: foram selecionados estudos clínicos de suplementação com BCAA`s, isolados ou em combinação com qualquer suplemento não proteico, com qualquer tempo de duração, em qualquer dose e em qualquer horário e forma de administração.

\subsection{Critérios de Exclusão}

As pesquisas foram excluídas em decorrência de: ensaios com animais, revisão de literatura. Cabe ressaltar que os estudos de revisão foram utilizados para consulta da lista de referências bibliográficas; estudos que investigaram o uso do suplemento em indivíduos com doenças específicas relacionadas à degradação da massa muscular, tal como HIV+, estudos com idosos sarcopênicos.

\section{- $2^{a}$ etapa: Lista dos títulos e resumos}

A lista dos títulos e resumos obtidos fez parte da planilha, preenchida pelo primeiro pesquisador, onde também foram anotadas as razões para inclusão ou não dos estudos (Anexo 1). Em seguida, um segundo pesquisador teve acesso à lista dos artigos, e fez o mesmo processo de inclusão ou não, preenchendo a sua planilha.

\section{- $3^{a}$ etapa:}

As duas planilhas, preenchidas segundo a inclusão dos estudos pelos pesquisadores, foram confrontadas, e em seguida foi realizada uma reunião de consenso entre os pesquisadores. 
- $4^{a}$ etapa:

Após o estabelecimento do consenso quanto aos artigos incluídos, o primeiro pesquisador procedeu à busca de todos os artigos na íntegra. Com os artigos/estudos em mãos, ele fez a leitura e a extração dos dados. Foram descritos em uma planilha o tipo de desfecho; sexo e grau de condicionamento dos participantes; idade dos participantes; desenho do estudo; descrição do suplemento e placebo; tempo de intervenção; desfecho e medidas; tamanho da amostra inicial e final; principais resultados e conclusões; risco de viés. As informações que foram levadas em consideração para a inclusão desses estudos nesta etapa estão descritas a seguir.

\section{Tipos de desfechos primários (Variáveis dependentes):}

a) Massa muscular esquelética (por antropometria, DXA ou BIA, tomografia Computadorizada ou ressonância magnética), massa de gordura corporal e marcadores de síntese proteica. Os resultados das medidas dessas variáveis foram analisados numericamente (em $\mathrm{kg}$ ou \%) e ou categoricamente.

b) Massa de gordura corporal (avaliada como gordura corporal total, por diferentes métodos), ou ainda a avaliação da distribuição da gordura corporal (por exemplo, a partir da medida da circunferência da cintura).

c) Marcadores de síntese proteica

Os resultados das medidas dessas variáveis foram analisados numericamente ( em $\mathrm{kg} \mathrm{ou} \%$ ) e ou categoricamente.

\section{- 5 etapa: Avaliação do risco de viés dos artigos}

A partir da obtenção de todos os artigos, foi realizada a avaliação do risco de viés dos artigos, de acordo com:

a) Geração de sequência aleatória;

b) Ocultação da alocação;

c) Cegamento dos participantes e pessoal;

d) Cegamento da avaliação dos resultados;

e) Dados de resultados incompletos;

f) Relatórios seletivos; 
g) Outras fontes de viés.

A avaliação desses parâmetros é que permitiu a inclusão ou não dos estudos. Foi necessário entrar em contato com os autores dos estudos para solicitar informações mais detalhadas omitidas ou pouco claras na publicação.

- $6^{a}$ etapa- Preenchimento das planilhas dos estudos e $7^{a}$ etapa-reunião de consenso:

Essas etapas foram realizadas novamente pelos dois pesquisadores, e em seguida foi realizada uma nova reunião de consenso para comparação do preenchimento das planilhas e inclusão/exclusão de estudos. Assim, a partir do consenso, os estudos foram agrupados de acordo com a proposta da colaboração Cochrane, descrita a seguir:

a) Estudos com Alto risco de viés: se na tabela de avaliação de risco de viés do trabalho tivesse pelo menos um critério classificado como " alto risco", ele deveria ser enquadrado como "alto risco";

b) Estudos com baixo risco de viés: se na tabela de avaliação de risco de viés do trabalho tivesse 2 ou mais critérios classificados como "baixo risco", ele se enquadraria como "baixo risco";

c) Estudos pouco claros: significa que, na tabela de avaliação de risco de viés o trabalho tivesse 2 ou mais critérios classificados como " pouco claro", ele se enquadraria como "pouco claro";

Após esta classificação, foram inseridos em uma coluna da planilha de avaliação de risco de viés, os estudos: "alto risco", "baixo risco" e "pouco claro". Os artigos classificados como "baixo risco" e "pouco claro" foram incluídos. Os artigos classificados como "alto risco" foram excluídos.

- 8a etapa: Agrupamento dos estudos por semelhança, avaliação da qualidade.

A partir da análise da qualidade, foram apresentados os dados da revisão sistemática. Os resultados foram apresentados de acordo com a semelhança entre os estudos. 
- $9^{a}$ etapa: Elaboração do relatório final e das publicações

Os resultados da revisão sistemática foram divididos em três partes:

a) Descrição dos estudos;

b) Qualidade dos estudos;

c) Resultado das variáveis.

$\mathrm{Na}$ interpretação dos resultados, foi determinada, a aplicabilidade dos resultados, as informações sobre a prática corrente e tudo mais que fosse relevante para determinação clara dos limites entre riscos e benefícios. 


\section{RESULTADOS}

- Ia etapa: Localização e seleção dos estudos primários

A busca dos artigos nas bases de dados, segundo as palavras-chave pré-determinadas, resultou em 7502 artigos. O número de artigos identificados em cada fonte está descrito na figura 5. Seguindo todos os critérios de inclusão estabelecidos, dos artigos publicados no período estabelecido (janeiro de 2009 até 2015), foram selecionados 196 estudos.

Total de estudos identificados $(n=7502)$

Highwire Stanford include Pubmed search $(n=1819)$

Lilacs and Medline search $(n=5683)$

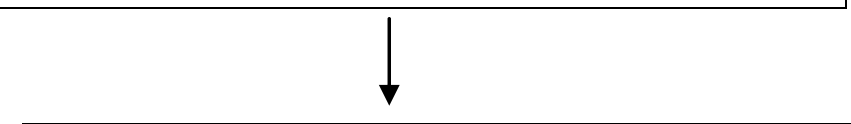

Estudos Selecionados $(\mathrm{n}=196)$

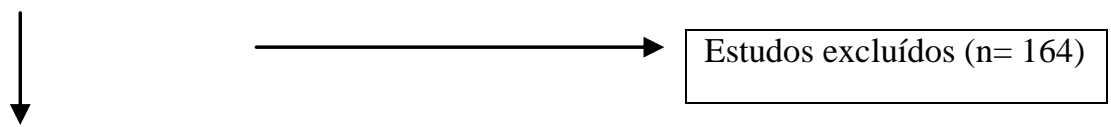

Estudos Selecionados pelos dois pesquisadores $(n=32)$

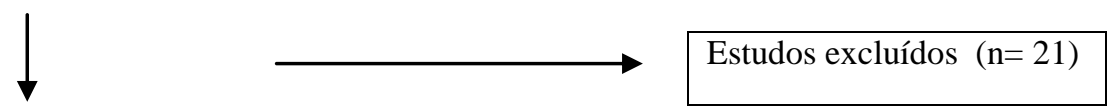

Estudos para coleta dos dados $(\mathrm{n}=11)$

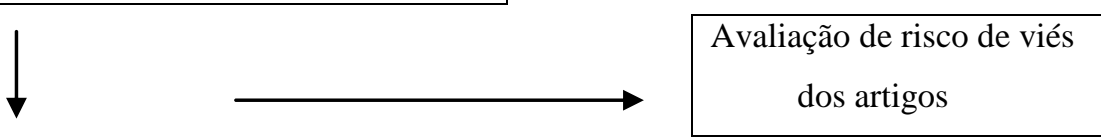

Estudos incluídos na análise qualitativa $(\mathrm{n}=11)$

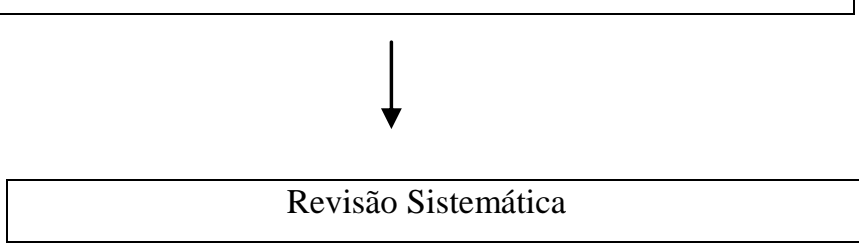

Figura 5. Fluxograma do estudo.

Seguindo todos os critérios de exclusão estabelecidos, dos 196 artigos selecionados, foram excluídos 164, restando 32 artigos relacionados na tabela 1. 
Tabela 1. Sumário dos estudos incluídos segundo os critérios de inclusão.

\begin{tabular}{|c|c|c|c|}
\hline Resultados & Referência Completa & Intervenção & Tipo do Estudo \\
\hline \multirow{7}{*}{$\begin{array}{l}\text { Ganho de Massa } \\
\text { e força muscular }\end{array}$} & $\begin{array}{l}\text { 1. Apró MBW, Blomstrand E. Intake of branched-chain amino acids influences the levels } \\
\text { of MAFbx mRNA and MuRF-1 total protein in resting and exercising human muscle. Am } \\
\text { J Physiol Endocrinol Metab 302: E510-E521, } 2012 .\end{array}$ & $\begin{array}{c}\text { Ingestão de isoleucina, valina } \\
\text { e leucina }\end{array}$ & $\begin{array}{l}\text { Duplo-cego cruzado } \\
\text { randomizado }\end{array}$ \\
\hline & $\begin{array}{c}\text { 2.Brooks N, Cloutier GJ, Cadena SM, Layne JE, Nelsen AC, Freed MA, Roubenoff R, } \\
\text { Castaneda-Sceppa C. Resistance training and timed essential amino acids protect against } \\
\text { the loss of muscle mass and strength during } 28 \text { days of bed rest and energy deficit. J Appl } \\
\text { Physiol 105:241-248, } 2008 \text {. }\end{array}$ & $\begin{array}{l}\text { Treinamento resistido e } \\
\text { suplementação de } \\
\text { aminoácidos }\end{array}$ & $\begin{array}{l}\text { Randomizado } \\
\text { controlado }\end{array}$ \\
\hline & $\begin{array}{l}\text { 3.Glynn EL, Fry CS, Timmerman LK, Drummond MJ, Volpi E, Rasmussen BB. Addition } \\
\text { of Carbohydrate or alanine to an Essential Amino Acid Mixture does not enhance Human } \\
\text { Skeletal muscle protein anabolism. J. Nutr. 143: 307-314, } 2013 \text {. }\end{array}$ & $\begin{array}{l}\text { Ingestão de aminoácidos } \\
\text { essenciais }\end{array}$ & $\begin{array}{l}\text { Randomizado } \\
\text { controlado }\end{array}$ \\
\hline & $\begin{array}{l}\text { 4.Pasiakos SM, McClung HL, McClung JP, Margolis ML, Andersen NE, Cloutier GJ, } \\
\text { Pikosky MA, Rood JC, Fielding RA, Young AJ. Leucine-enriched essential amino acid } \\
\text { supplementation during moderate steady state exercise enhances postexercise muscle } \\
\text { protein synthesis. Am J Clin Nutr 2011;94:809-18. }\end{array}$ & $\begin{array}{l}\text { Suplementação de leucina } \\
\text { enriquecida com aminoácidos } \\
\text { essenciais e exercício }\end{array}$ & $\begin{array}{l}\text { Randomizado } \\
\text { controlado }\end{array}$ \\
\hline & $\begin{array}{l}\text { 5.Dickinson JM, Fry CS, Drummond MJ, Gundermann DM, Walker DK, Glynn EL, } \\
\text { Timmerman KL, Dhanani S, Volpi E, Rasmussen BK. Mammalian Target of Rapamycin } \\
\text { Complex } 1 \text { Activation Is Required for the Stimulation of Human Skeletal Muscle Protein } \\
\text { Synthesis by Essential Amino Acids. J. Nutr. 141: 856-862, } 2011 \text {. }\end{array}$ & $\begin{array}{c}\text { Ingestão de aminoácidos } \\
\text { essenciais }\end{array}$ & $\begin{array}{l}\text { Randomizado } \\
\text { controlado }\end{array}$ \\
\hline & $\begin{array}{l}\text { 6.Drummond MJ, Miyazaki M, Dreyer HC, Pennings B, Dhanani S, Volpi E, Esser KA, } \\
\text { Rasmussen, BB. Expression of growth-related genes in young and older human skeletal } \\
\text { muscle following an acute stimulation of protein synthesis } \\
\text { J Appl Physiol 106: 1403-1411, } 2009\end{array}$ & $\begin{array}{l}\text { Ingestão de aminoácidos } \\
\text { essenciais combinado com } \\
\text { exercício resistido }\end{array}$ & $\begin{array}{l}\text { Randomizado } \\
\text { controlado }\end{array}$ \\
\hline & $\begin{array}{l}\text { 7.Verhoeven S, Vanschoonbeek K, Verdijk LB, Koopman R, Wodzig WLWH, Dendale P, } \\
\text { Loon LJCV. Long-term leucine supplementation does not increase muscle mass or } \\
\text { strength in healthy elderly men. Am J Clin Nutr 2009;89:1468-75 }\end{array}$ & Suplementação de leucina & $\begin{array}{l}\text { Randomizado } \\
\text { controlado }\end{array}$ \\
\hline
\end{tabular}


Tabela 1. Sumário dos estudos incluídos segundo os critérios de inclusão (cont.)

\begin{tabular}{|c|c|c|c|}
\hline Resultados & Referência Completa & Intervenção & Tipo do Estudo \\
\hline \multirow{7}{*}{$\begin{array}{l}\text { Ganho de } \\
\text { Massa e força } \\
\text { muscular }\end{array}$} & $\begin{array}{l}\text { 8.Wilkinson1 DJ, HossainT, Hill DS, Phillips BE, Crossland H, Williams J, LoughnaP, } \\
\text { Churchward-Venne TA, Breen L, Phillips SM, Etheridge T, Rathmacher JA, Smith K, } \\
\text { Szewczyk NJ, Atherton PJ. Effects of leucine and its metabolite } \beta \text {-hydroxy- } \beta \text { - } \\
\text { methylbutyrate on human skeletal muscle protein metabolism. J Physiol 591.11 (2013) pp } \\
\text { 2911-2923 }\end{array}$ & Suplementação de leucina & $\begin{array}{l}\text { Randomizado } \\
\text { controlado }\end{array}$ \\
\hline & $\begin{array}{c}\text { 9.Onambélé-Pearson GL, Breen L, Stewart CE.Influences of carbohydrate plus amino acid } \\
\text { supplementation on differing exercise intensity adaptations in older persons: skeletal } \\
\text { muscle and endocrine responses.AGE (2010) 32:125-138 }\end{array}$ & $\begin{array}{l}\text { Suplementação de aminoácidos } \\
\text { com carboidrato, associado a } \\
\text { exercício resistido }\end{array}$ & $\begin{array}{l}\text { Randomizado } \\
\text { controlado }\end{array}$ \\
\hline & $\begin{array}{l}\text { 10.Glynn EL, Fry CS, Drummond MJ, Dreyer HC, Dhanani S,Volpi E, Rasmussen } \\
\text { BB.Muscle protein breakdown has a minor role in the protein anabolic response to essential } \\
\text { amino acid and carbohydrate intake following resistance exercise } \\
\text { Am J Physiol Regul Integr Comp Physiol 299: R533-R540, } 2010\end{array}$ & $\begin{array}{l}\text { Suplementação de carboidrato } \\
\text { com aminoácidos essenciais e } \\
\text { exercício }\end{array}$ & $\begin{array}{l}\text { Randomizado } \\
\text { controlado }\end{array}$ \\
\hline & $\begin{array}{l}\text { 11. Vieillevoye S; Poortmans JR; Duchateau J; Carpentier.Effects of a combined essential } \\
\text { amino acids/carbohydrate supplementation on muscle mass, architecture and maximal } \\
\text { strength following heavy-load training.A.Eur J Appl Physiol; 110(3): 479-88, } 2010 \text { Oct. }\end{array}$ & $\begin{array}{l}\text { Suplementação de aminoácidos } \\
\text { essenciais com carboidrato com } \\
\text { treinamento }\end{array}$ & $\begin{array}{l}\text { Randomizado } \\
\text { controlado }\end{array}$ \\
\hline & $\begin{array}{l}\text { 12.Kawada S, Okamoto Y. Resistance exercise combined with essential amino acid } \\
\text { supplementation improved walking ability in elderly people. Acta Physiol Hungarica; } \\
100(3), 329-339,2013\end{array}$ & $\begin{array}{c}\text { Suplementação de aminoácidos } \\
\text { essenciais e exercício }\end{array}$ & $\begin{array}{l}\text { Randomizado } \\
\text { controlado }\end{array}$ \\
\hline & $\begin{array}{c}\text { 13.Dickinson JM, Drummond MJ, Coben JR, Volpi E, Rasmussen BB.Aging differentially } \\
\text { affects human skeletal muscle amino acid transporter expression when essential amino } \\
\text { acids are ingested after exercise.Clin Nutr . } 2013 \text { April ; 32(2): 273-280. } \\
\text { doi:10.1016/j.clnu.2012.07.009 }\end{array}$ & $\begin{array}{l}\text { Suplementação de aminoácidos } \\
\text { essenciais e exercício resistido }\end{array}$ & $\begin{array}{l}\text { Randomizado } \\
\text { controlado }\end{array}$ \\
\hline & $\begin{array}{l}\text { 14.Tatpati LL; Irving BA; Tom A; Bigelow ML; Klaus K; Short KR; Nair KS .The effect of } \\
\text { branched chain amino acids on skeletal muscle mitochondrial function in young and elderly } \\
\text { adults. J Clin Endocrinol Metab;95(2): 894-902, } 2010 \text { Feb }\end{array}$ & Suplementação de BCAA & $\begin{array}{l}\text { Randomizado } \\
\text { controlado }\end{array}$ \\
\hline
\end{tabular}


Tabela 1. Sumário dos estudos incluídos segundo os critérios de inclusão (cont.)

\begin{tabular}{|c|c|c|c|}
\hline Resultados & Referência Completa & Intervenção & Tipo do Estudo \\
\hline \multirow{2}{*}{$\begin{array}{c}\text { Ganho de } \\
\text { Massa e força } \\
\text { muscular }\end{array}$} & $\begin{array}{l}\text { 15. Ferreira MP, Li R, Cooke M, Kreider RB, Willoughby DS.Periexercise coingestion of } \\
\text { branchedchain amino acids and carbohydrate in men does not preferentially augment } \\
\text { resistance exercise induced increases in phosphatidylinositol } 3 \text { kinase/protein kinase B } \\
\text { mammalian target of rapamycin pathway markers indicative of muscle protein } \\
\text { synthesis.Nutrition research (New York, N.Y.) } 2014 \text { Vol } 34 \text { (3): 19-18 }\end{array}$ & $\begin{array}{l}\text { Suplementação de BCAA } \\
\text { associado com carboidrato e } \\
\text { exercício resistido }\end{array}$ & $\begin{array}{l}\text { Randomizado } \\
\text { controlado }\end{array}$ \\
\hline & $\begin{array}{l}\text { 16.Apró W, Blomstrand E.Influence of supplementation with branchedchain amino acids in } \\
\text { combination with resistance exercise on p70S6 kinase } \\
\text { phosphorylation in resting and exercising human skeletal muscle.Acta physiologica. } \\
2010 \text { Nov Vol } 200 \text { (3): } 23748\end{array}$ & $\begin{array}{l}\text { Suplementação de BCAA e } \\
\text { exercício resistido }\end{array}$ & $\begin{array}{l}\text { Randomizado } \\
\text { controlado }\end{array}$ \\
\hline \multirow{5}{*}{ Performance } & $\begin{array}{l}\text { 1.Peltier SL, Vincent L, Millet GY, Sirvent P, Morin JB, Guerraz M, Geyssant A, Lescuyer } \\
\text { JF, Feasson L, Messonnier L. Effects of carbohydrates-BCAAs-caffeine ingestion on } \\
\text { performance and neuromuscular function during a 2-h treadmill run: a randomized, } \\
\text { doubleblind, cross-over placebo-controlled study. Journal of the International Society of } \\
\text { Sports Nutrition 2011, } 8: 22\end{array}$ & $\begin{array}{l}\text { Associação de BCAA com } \\
\text { cafeína e carboidrato }\end{array}$ & $\begin{array}{l}\text { Duplo-cego } \\
\text { randomizado }\end{array}$ \\
\hline & $\begin{array}{l}\text { 2.Hackney KJ, Kelleher AR, Ploutz-Snyder LL. Amino Acid-Carbohydrate Intake } \\
\text { Combined with Multiple Bouts of Resistance Exercise Increases Resting Energy } \\
\text { ExpenditureISRNNutrition Volume2013,ArticleID948695,6pages }\end{array}$ & $\begin{array}{l}\text { Suplementação de aminoácidos } \\
\text { essenciais com carboidrato e } \\
\text { exercício resistido }\end{array}$ & $\begin{array}{l}\text { Randomizado } \\
\text { controlado }\end{array}$ \\
\hline & $\begin{array}{l}\text { 3. Wisnik P; Chmura J; Ziemba AW; Mikulski T; Nazar K.The effect of branched chain } \\
\text { amino acids on psychomotor performance during treadmill exercise of changing intensity } \\
\text { simulating a soccer game. Appl Physiol Nutr Metab;36(6): 856-62, } 2011 \mathrm{Dec}\end{array}$ & $\begin{array}{c}\text { Suplementação de BCAA em } \\
\text { jogadores de futebol }\end{array}$ & $\begin{array}{l}\text { Randomizado } \\
\text { controlado }\end{array}$ \\
\hline & $\begin{array}{c}\text { 4.Greer BK; White JP; Arguello EM; Haymes EM. Branched-chain amino acid } \\
\text { supplementation lowers perceived exertion but does not affect performance in untrained } \\
\text { males. J Strength Cond Res;25(2):539-44, } 2011 \text { Feb. }\end{array}$ & $\begin{array}{l}\text { Suplementação de BCAA e } \\
\text { carboidrato }\end{array}$ & $\begin{array}{l}\text { Randomizado } \\
\text { controlado }\end{array}$ \\
\hline & $\begin{array}{l}\text { 5. Matsumoto , Oba T, Hamada, Tsujimoto H, Mitsuzono R.Branched-chain amino acid } \\
\text { supplementation increases the lactate threshold during na incremental exercise test in } \\
\text { trained individuals. Journal of nutritional science and vitaminology.2009 Feb. Vol } 55 \text { (1): } \\
528\end{array}$ & $\begin{array}{l}\text { Suplementação de BCAA com } \\
\text { carboidrato e exercício }\end{array}$ & $\begin{array}{l}\text { Duplo-cego cruzado } \\
\text { randomizado }\end{array}$ \\
\hline
\end{tabular}


Tabela 1. Sumário dos estudos incluídos segundo os critérios de inclusão (cont.)

\begin{tabular}{|c|c|c|c|}
\hline Resultados & Referência Completa & Intervenção & Tipo do Estudo \\
\hline Performance & $\begin{array}{l}\text { 6.Gualano AB, Bozza T, Lopes De Campos P, Roschel H, Dos Santos Costa A, Luiz } \\
\text { Marquezi M, Benatti F, Herbert Lancha Junior A.Branchedchain amino acids } \\
\text { supplementation enhances exercise capacity and lipid oxidation during endurance exercise } \\
\text { after muscle glycogen depletion.Journal of sports medicine and physical fitness. } 2011 \text { Mar } \\
\text { Vol } 51 \text { (1):828 }\end{array}$ & $\begin{array}{l}\text { Suplementação de BCAA } \\
\text { associado a exercício }\end{array}$ & $\begin{array}{l}\text { Duplo-cego cruzado } \\
\text { randomizado }\end{array}$ \\
\hline \multirow{6}{*}{$\begin{array}{l}\text { Dor, dano e } \\
\text { inflamação } \\
\text { muscular }\end{array}$} & $\begin{array}{l}\text { 1.Matsumoto K, Koba T, Hamada K, Sakurai M, Higuchi T, Miyata H.Branched-chain } \\
\text { amino acid supplementation attenuates muscle soreness, muscle damage and inflammation } \\
\text { during an intensive training program.Journal of sports medicine and physical fitness. } \\
\text { 2009 Dec Vol } 49 \text { (4): } 42431\end{array}$ & $\begin{array}{l}\text { Suplementação de BCAA } \\
\text { associado a treinamento } \\
\text { intensivo }\end{array}$ & $\begin{array}{l}\text { Duplo-cego cruzado } \\
\text { randomizado }\end{array}$ \\
\hline & $\begin{array}{c}\text { 2.Howatson G, Hoad M, Goodall S, Tallent J, Bell PG, French DN.Exercise-induced } \\
\text { muscle damage is reduced in resistance-trained males by branched chain amino acids: a } \\
\text { randomized, double-blind, placebo controlled study.Journal of the International Society of } \\
\text { Sports Nutrition 2012, 9:20 }\end{array}$ & $\begin{array}{l}\text { Suplementação de BCAA } \\
\text { associado a exercício }\end{array}$ & $\begin{array}{l}\text { Duplo-cego } \\
\text { randomizado }\end{array}$ \\
\hline & $\begin{array}{c}\text { 3..Leahyand DT, Pintauro SJ .Branched-Chain Amino Acid Plus Glucose Supplement } \\
\text { Reduces Exercise-Induced Delayed Onset Muscle Soreness in College-Age Females } \\
\text { ISRNNutrition Volume2013,ArticleID921972,5pages }\end{array}$ & $\begin{array}{l}\text { Suplementação de BCAA com } \\
\text { glicose }\end{array}$ & $\begin{array}{l}\text { Duplo-cego cruzado } \\
\text { randomizado }\end{array}$ \\
\hline & $\begin{array}{l}\text { 4.Areces F; Salinero JJ; Abian-Vicen J; González-Millán C; Gallo-Salazar C; Ruiz-Vicente } \\
\text { D; Lara B; Del Coso J.A 7-day oral supplementation with branched-chain amino acids was } \\
\text { ineffective to prevent muscle damage during a marathon.Amino Acids;46(5):1169-76, } 2014 \\
\text { May. }\end{array}$ & $\begin{array}{c}\text { Suplementação de BCAA } \\
\text { em maratonistas }\end{array}$ & $\begin{array}{l}\text { Randomizado } \\
\text { controlado }\end{array}$ \\
\hline & $\begin{array}{l}\text { 5.Knechtle B; Mrazek C; Wirth A; Knechtle P; Rüst CA; Senn O; Rosemann T; Imoberdorf } \\
\text { R; Ballmer P. Branched-chain amino acid supplementation during a 100-km ultra- } \\
\text { marathon--a randomized controlled trial.J Nutr Sci Vitaminol (Tokyo);58(1):36-44, } 2012 .\end{array}$ & $\begin{array}{c}\text { Suplementação de BCAA em } \\
\text { maratonistas }\end{array}$ & $\begin{array}{l}\text { Randomizado } \\
\text { controlado }\end{array}$ \\
\hline & $\begin{array}{l}\text { 6.Sharp CP; Pearson DR. Amino acid supplements and recovery from high-intensity } \\
\text { resistance training. J Strength Cond Res;24(4):1125-30, } 2010 \text { Apr. }\end{array}$ & $\begin{array}{c}\text { Suplementação de BCAA } \\
\text { associado a treinamento resistido }\end{array}$ & $\begin{array}{l}\text { Randomizado } \\
\text { controlado }\end{array}$ \\
\hline
\end{tabular}


Tabela 1. Sumário dos estudos incluídos segundo os critérios de inclusão (cont.)

\begin{tabular}{|c|c|c|c|}
\hline Resultados & Referência Completa & Intervenção & Tipo do Estudo \\
\hline \multirow{4}{*}{ Outros } & $\begin{array}{l}\text { 1.Pencharz PB, Elango R, Ball RO. Determination of the Tolerable Upper Intake Level of } \\
\text { Leucine in Adult Men. J. Nutr. 142: 2220S-2224S, } 2012\end{array}$ & $\begin{array}{l}\text { Ingestão de aminoácidos } \\
\text { essenciais isolados e associados } \\
\text { com carboidrato }\end{array}$ & $\begin{array}{l}\text { Randomizado } \\
\text { controlado }\end{array}$ \\
\hline & $\begin{array}{c}\text { 2. Spillane M; Emerson C; Willoughby DS. The effects of } 8 \text { weeks of heavy resistance } \\
\text { training and branched-chain amino acid supplementation on body composition and muscle } \\
\text { performance. Nutr Health;21(4):263-73, } 2012 \text { Oct. }\end{array}$ & $\begin{array}{l}\text { Suplementação isolada ou } \\
\text { combinada com maltodextrina }\end{array}$ & $\begin{array}{l}\text { Randomizado } \\
\text { controlado }\end{array}$ \\
\hline & $\begin{array}{l}\text { 3.Coeffier M, Claeyssens S, Bensifi M, Lecleire S, Boukhettala N, Maurer B, Donnadieu N, } \\
\text { Lavoinne A, Cailleux AF, De 'chelotte P. Influence of leucine on protein metabolism, } \\
\text { phosphokinase expression, and cell proliferation in human duodenum. Am J Clin Nutr } \\
\text { 2011;93:1255-62 }\end{array}$ & $\begin{array}{l}\text { Suplementação de leucina } \\
\text { isolada e associada com } \\
\text { maltodextrina }\end{array}$ & $\begin{array}{l}\text { Randomizado } \\
\text { controlado }\end{array}$ \\
\hline & $\begin{array}{l}\text { 4. Shimomura Y, Kobayashi } \mathrm{H} \text {, Mawatari } \mathrm{K} \text {, Akita K, Inaguma A, Watanabe S, Bajotto G, } \\
\text { Sato J. Effects of squat exercise and branchedchain amino acid supplementation on plasma } \\
\text { free amino acid concentrations in young women. Journal of nutritional science and } \\
\text { vitaminology } .2009 \text { Jun. Vol.55 (3): } 28891\end{array}$ & $\begin{array}{l}\text { Suplementação de BCAA } \\
\text { associado a exercício }\end{array}$ & $\begin{array}{l}\text { Randomizado } \\
\text { controlado }\end{array}$ \\
\hline
\end{tabular}


As justificativas para a exclusão dos estudos constam da tabela 2 .

Tabela 2. Sumário dos estudos excluídos segundo os critérios de exclusão Motivo da exclusão de estudos Número de Estudos

Duplicidade 46

Revisão 48

Associados a doenças

Estudos epidemiológicos

05

Suplementação com nutrientes proteicos, dietas

60

\section{- 2a etapa: Lista dos títulos e resumos}

A lista dos títulos e resumos dos 32 artigos selecionados foi relacionada em uma planilha, preenchida pelo primeiro pesquisador, onde também foram anotadas as razões para inclusão ou não dos estudos.

A planilha com a lista dos títulos e resumos foi enviada para o segundo pesquisador que preencheu sua planilha, seguindo o mesmo processo de inclusão ou não.

Seguindo os critérios de exclusão, foram excluídos 21 artigos. As justificativas para exclusão dos 21 estudos constam da tabela 3.

Tabela 3. Sumário dos estudos excluídos segundo os critérios de exclusão

\section{Motivo da exclusão de estudos}

Suplementação com aminoácidos

Suplementação com proteína
Número de Estudos

19

2

\section{- $3^{a}$ etapa e $4^{a}$ etapa: Busca dos artigos completos}

Após o estabelecimento do consenso quanto aos artigos incluídos, o primeiro pesquisador procedeu à busca dos 11 artigos completos, realizando a leitura e extração dos dados necessários para avaliação do risco de viés dos estudos (tabela 4). 
Tabela 4 - Sumário da avaliação do risco de viés.

\begin{tabular}{|c|c|c|c|c|c|c|c|}
\hline \multicolumn{8}{|c|}{ AVALIAÇÃO DO RISCO DE VIÉS } \\
\hline \multicolumn{8}{|c|}{ FERRAMENTAS DA COLABORAÇÃO COCHRANE PARA AVALIAR O RISCO DE VIÉS } \\
\hline \multirow{2}{*}{$\begin{array}{c}\text { AUTO, ANO E } \\
\text { LOCAL DO } \\
\text { ESTUDO }\end{array}$} & \multicolumn{2}{|c|}{ VIÉS DE SELEÇÃO } & \multirow{2}{*}{$\begin{array}{c}\text { VIÉS DE } \\
\text { DESEMPENHO } \\
\text { CEGAMENTO DOS } \\
\text { PARTICIPANTES E } \\
\text { PESSOAL } \\
\end{array}$} & \multirow{2}{*}{$\begin{array}{c}\text { VIÉS DE } \\
\text { DETECÇÃO } \\
\text { CEGAMENTO DA } \\
\text { AVALIAÇÃO DOS } \\
\text { RESULTADOS } \\
\end{array}$} & \multirow{2}{*}{$\begin{array}{c}\text { VIÉS DE ATRITO } \\
\text { DADOS DOS } \\
\text { RESULTADOS } \\
\text { INCOMPLETOS }\end{array}$} & \multirow{2}{*}{$\begin{array}{c}\text { VIÉS DE } \\
\text { COMUNICAÇÃO } \\
\text { RELATÓRIOS } \\
\text { SELETIVOS }\end{array}$} & \multirow{2}{*}{$\begin{array}{c}\text { OUTRO VIÉS } \\
\text { OUTRAS } \\
\text { FONTES DE } \\
\text { VIÉS }\end{array}$} \\
\hline & $\begin{array}{c}\text { GERAÇÃO DE } \\
\text { SEQUENCIA } \\
\text { ALEATÓRIA } \\
\end{array}$ & $\begin{array}{l}\text { OCULTAÇÃO DA } \\
\text { ALOCAÇÃO }\end{array}$ & & & & & \\
\hline $\begin{array}{l}\text { Greer . } \\
(2011) \\
\text { (USA) }\end{array}$ & $\begin{array}{l}\text { - Os autores } \\
\text { referem alocação } \\
\text { randômica, mas } \\
\text { não explicitam. }\end{array}$ & $\begin{array}{l}\text { - O suplemento era } \\
\text { na forma liquida, e } \\
\text { os pesquisadores } \\
\text { descreveram os } \\
\text { cuidados para } \\
\text { manter as } \\
\text { aparências iguais. }\end{array}$ & $\begin{array}{l}\text { - Não foi feita } \\
\text { menção ao } \\
\text { cegamento. }\end{array}$ & $\begin{array}{l}\text { - Informação } \\
\text { insuficiente } \\
\text { para permitir o } \\
\text { julgamento }\end{array}$ & $\begin{array}{c}\text { - O estudo } \\
\text { iniciou e } \\
\text { terminou com } 9 \\
\text { indivíduos. }\end{array}$ & $\begin{array}{c}\text { - Não há } \\
\text { sugestão de } \\
\text { dados não } \\
\text { apresentados. }\end{array}$ & $\begin{array}{l}\text { - O estudo } \\
\text { parece estar } \\
\text { livre de outras } \\
\text { fontes de viés }\end{array}$ \\
\hline & Pouco claro & Baixo risco & Pouco claro & Pouco claro & Baixo risco & Baixo risco & Baixo risco \\
\hline \multirow[t]{2}{*}{$\begin{array}{l}\text { Gualano et al. } \\
\qquad(2011) \\
\text { (BRASIL) }\end{array}$} & $\begin{array}{l}\text { - Os autores } \\
\text { referem alocação } \\
\text { randômica, mas } \\
\text { não explicitam }\end{array}$ & $\begin{array}{l}\text { - Os autores } \\
\text { referem duplo } \\
\text { cego, mas não } \\
\text { fornecem detalhes }\end{array}$ & $\begin{array}{l}\text { Foi citado que } \\
\text { foi duplo cego, } \\
\text { mas não foi } \\
\text { fornecido o } \\
\text { detalhamento }\end{array}$ & $\begin{array}{l}\text { - Informação } \\
\text { insuficiente } \\
\text { para permitir o } \\
\text { julgamento }\end{array}$ & $\begin{array}{c}\text { - O estudo } \\
\text { iniciou e } \\
\text { terminou com } 7 \\
\text { indivíduos }\end{array}$ & $\begin{array}{c}\text { • Não há } \\
\text { sugestão de } \\
\text { dados não } \\
\text { apresentados }\end{array}$ & $\begin{array}{l}\text { - O estudo } \\
\text { parece estar } \\
\text { livre de outras } \\
\text { fontes de viés }\end{array}$ \\
\hline & Pouco claro & Pouco claro & Pouco claro & Pouco claro & Baixo risco & Baixo risco & Baixo risco \\
\hline \multirow[t]{2}{*}{$\begin{array}{l}\text { Peltier et al. } \\
\qquad(2011) \\
\text { (FRANÇA) }\end{array}$} & $\begin{array}{l}\text { - Não é feita } \\
\text { referência à } \\
\text { alocação dos } \\
\text { sujeitos }\end{array}$ & $\begin{array}{c}\text { - Os autores } \\
\text { descrevem que o } \\
\text { segredo só foi } \\
\text { rompido após a } \\
\text { conclusão de todas } \\
\text { as análises }\end{array}$ & $\begin{array}{l}\text { - Os autores } \\
\text { descrevem que o } \\
\text { segredo só foi } \\
\text { rompido após a } \\
\text { conclusão de } \\
\text { todas as análises }\end{array}$ & $\begin{array}{l}\text { - Informação } \\
\text { insuficiente } \\
\text { para permitir o } \\
\text { julgamento }\end{array}$ & $\begin{array}{c}\text { - O estudo } \\
\text { iniciou com } 13 \mathrm{e} \\
\text { terminou com } \\
11 \text { indivíduos } \\
\text { - Esses dropouts } \\
\text { não foram } \\
\text { investigados } \\
\end{array}$ & $\begin{array}{c}\text { • Não há } \\
\text { sugestão de } \\
\text { dados não } \\
\text { apresentados }\end{array}$ & $\begin{array}{l}\text { - O estudo } \\
\text { parece estar } \\
\text { livre de outras } \\
\text { fontes de viés }\end{array}$ \\
\hline & Pouco claro & Baixo risco & Baixo risco & Pouco claro & Baixo risco & Pouco claro & Baixo risco \\
\hline \multirow[t]{2}{*}{$\begin{array}{l}\text { Howatson et al. } \\
\qquad(2012)\end{array}$} & $\begin{array}{l}\text { - Não é feita } \\
\text { referência à } \\
\text { alocação dos } \\
\text { sujeitos }\end{array}$ & $\begin{array}{l}\text { - Os pesquisadores } \\
\text { descreveram os } \\
\text { cuidados de manter } \\
\text { as aparências } \\
\text { iguais. }\end{array}$ & $\begin{array}{l}\text { - Não foi feita } \\
\text { menção ao } \\
\text { cegamento }\end{array}$ & $\begin{array}{l}\text { - Informação } \\
\text { insuficiente } \\
\text { para permitir o } \\
\text { julgamento }\end{array}$ & $\begin{array}{l}\text { - Iniciou com } \\
12 \text { e terminou } \\
\text { com } 12 \\
\text { indivíduos }\end{array}$ & $\begin{array}{c}\text { • Não há } \\
\text { sugestão de } \\
\text { dados não } \\
\text { apresentados }\end{array}$ & $\begin{array}{l}\text { - O estudo } \\
\text { parece estar } \\
\text { livre de outras } \\
\text { fontes de viés }\end{array}$ \\
\hline & Pouco claro & Baixo risco & Baixo risco & Pouco claro & Baixo risco & Baixo risco & Baixo risco \\
\hline
\end{tabular}


Tabela 4 - Sumário da avaliação do risco de viés (cont.)

\begin{tabular}{|c|c|c|c|c|c|c|c|}
\hline \multicolumn{8}{|c|}{ AVALIAÇÃO DO RISCO DE VIÉS } \\
\hline \multicolumn{8}{|c|}{ FERRAMENTAS DA COLABORAÇÃO COCHRANE PARA AVALIAR O RISCO DE VIÉS } \\
\hline \multirow{2}{*}{$\begin{array}{l}\text { AUTO, ANO E } \\
\text { LOCAL DO } \\
\text { ESTUDO }\end{array}$} & \multicolumn{2}{|c|}{ VIÉS DE SELEÇÃO } & \multirow{2}{*}{$\begin{array}{c}\text { VIÉS DE } \\
\text { DESEMPENHO } \\
\text { CEGAMENTO DOS } \\
\text { PARTICIPANTES E } \\
\text { PESSOAL } \\
\end{array}$} & \multirow{2}{*}{$\begin{array}{c}\text { VIÉS DE } \\
\text { DETECÇÃO } \\
\text { CEGAMENTO DA } \\
\text { AVALIAÇÃO DOS } \\
\text { RESULTADOS } \\
\end{array}$} & \multirow{2}{*}{$\begin{array}{c}\text { VIÉS DE ATRITO } \\
\text { DADOS DOS } \\
\text { RESULTADOS } \\
\text { INCOMPLETOS }\end{array}$} & \multirow{2}{*}{$\begin{array}{c}\text { VIÉS DE } \\
\text { COMUNICAÇÃO } \\
\text { RELATÓRIOS } \\
\text { SELETIVOS }\end{array}$} & \multirow{2}{*}{$\begin{array}{c}\text { OUTRO VIÉS } \\
\text { OUTRAS } \\
\text { FONTES DE } \\
\text { VIÉS } \\
\end{array}$} \\
\hline & $\begin{array}{l}\text { GERAÇÃO DE } \\
\text { SEQUENCIA } \\
\text { ALEATÓRIA } \\
\end{array}$ & $\begin{array}{l}\text { OCULTAÇÃO DA } \\
\text { ALOCAÇÃO }\end{array}$ & & & & & \\
\hline \multirow[t]{2}{*}{$\begin{array}{c}\text { Apró \& } \\
\text { Blomstand } \\
\quad(2009) \\
\text { (SUÉCIA) }\end{array}$} & $\begin{array}{l}\text { - Não é feita } \\
\text { referência à } \\
\text { alocação dos } \\
\text { sujeitos }\end{array}$ & $\begin{array}{l}\text { - Os pesquisadores } \\
\text { descreveram os } \\
\text { cuidados de manter } \\
\text { as aparências } \\
\text { iguais. }\end{array}$ & $\begin{array}{l}\text { Foi citado que } \\
\text { foi duplo cego, } \\
\text { mas não foi } \\
\text { fornecido o } \\
\text { detalhamento }\end{array}$ & $\begin{array}{l}\text { - Informação } \\
\text { insuficiente } \\
\text { para permitir o } \\
\text { julgamento }\end{array}$ & $\begin{array}{l}\text { - Iniciou com } 9 \\
\text { e terminou com } \\
9\end{array}$ & $\begin{array}{c}\text { • Não há } \\
\text { sugestão de } \\
\text { dados não } \\
\text { apresentados }\end{array}$ & $\begin{array}{l}\text { - O estudo } \\
\text { parece estar } \\
\text { livre de outras } \\
\text { fontes de viés }\end{array}$ \\
\hline & Pouco claro & Baixo risco & Pouco claro & Pouco claro & Baixo risco & Baixo risco & Baixo risco \\
\hline \multirow[t]{2}{*}{$\begin{array}{l}\text { Borgenvik et al. } \\
\qquad(2011)\end{array}$} & $\begin{array}{l}\text { - Não é feita } \\
\text { referência à } \\
\text { alocação dos } \\
\text { sujeitos }\end{array}$ & $\begin{array}{l}\text { - Os pesquisadores } \\
\text { descreveram os } \\
\text { cuidados de manter } \\
\text { as aparências e } \\
\text { sabores iguais. }\end{array}$ & $\begin{array}{l}\text { Foi citado que } \\
\text { foi duplo cego, } \\
\text { mas não foi } \\
\text { fornecido o } \\
\text { detalhamento }\end{array}$ & $\begin{array}{l}\text { - Informação } \\
\text { insuficiente } \\
\text { para permitir o } \\
\text { julgamento }\end{array}$ & $\begin{array}{l}\text { - Iniciou com } 7 \\
\text { e terminou com } \\
7\end{array}$ & $\begin{array}{c}\text { - Não há } \\
\text { sugestão de } \\
\text { dados não } \\
\text { apresentados }\end{array}$ & $\begin{array}{l}\text { - O estudo } \\
\text { parece estar } \\
\text { livre de outras } \\
\text { fontes de viés }\end{array}$ \\
\hline & Pouco claro & Baixo risco & Pouco claro & Pouco claro & Baixo risco & Baixo risco & Baixo risco \\
\hline \multirow[t]{2}{*}{$\begin{array}{l}\text { Ferreira et al. } \\
\qquad(2013)\end{array}$} & $\begin{array}{l}\text { - Os sujeitos } \\
\text { foram convocados } \\
\text { por telefone e } \\
\text { somente } \\
\text { participaram os } \\
\text { que atendiam aos } \\
\text { critérios adotados }\end{array}$ & $\begin{array}{l}\text { - Os pesquisadores } \\
\text { descreveram os } \\
\text { cuidados de manter } \\
\text { as aparências e } \\
\text { sabores iguais. }\end{array}$ & $\begin{array}{l}\text { Foi citado que } \\
\text { foi duplo cego, } \\
\text { mas não foi } \\
\text { fornecido o } \\
\text { detalhamento }\end{array}$ & $\begin{array}{l}\text { - Informação } \\
\text { insuficiente } \\
\text { para permitir o } \\
\text { julgamento }\end{array}$ & $\begin{array}{l}\text { - Iniciou com } \\
\text { 27e terminou } \\
\text { com } 27\end{array}$ & $\begin{array}{c}\text { • Não há } \\
\text { sugestão de } \\
\text { dados não } \\
\text { apresentados }\end{array}$ & $\begin{array}{l}\text { - O estudo } \\
\text { parece estar } \\
\text { livre de outras } \\
\text { fontes de viés }\end{array}$ \\
\hline & Baixo risco & Baixo risco & Pouco claro & Pouco claro & Baixo risco & Baixo risco & Baixo risco \\
\hline \multirow[t]{2}{*}{$\begin{array}{l}\text { Tatpat et al. } \\
\text { (2010) } \\
\text { (USA) }\end{array}$} & $\begin{array}{l}\text { - Os autores } \\
\text { referem alocação } \\
\text { randômica, mas } \\
\text { não explicitam }\end{array}$ & $\begin{array}{l}\text { - O suplemento e o } \\
\text { placebo tinham a } \\
\text { mesma aparência }\end{array}$ & $\begin{array}{l}\text { - Não foi feita } \\
\text { menção ao } \\
\text { cegamento }\end{array}$ & $\begin{array}{l}\text { - Informação } \\
\text { insuficiente } \\
\text { para permitir o } \\
\text { julgamento }\end{array}$ & $\begin{array}{l}\text { - Iniciou com } \\
24 \text { e terminou } \\
\text { com } 24\end{array}$ & $\begin{array}{c}\text { - Não há } \\
\text { sugestão de } \\
\text { dados não } \\
\text { apresentados }\end{array}$ & $\begin{array}{l}\text { - O estudo } \\
\text { parece estar } \\
\text { livre de outras } \\
\text { fontes de viés }\end{array}$ \\
\hline & Pouco claro & Baixo risco & Baixo risco & Pouco claro & Baixo risco & Baixo risco & Baixo risco \\
\hline
\end{tabular}


Tabela 4 - Sumário da avaliação do risco de viés (cont.)

\begin{tabular}{|c|c|c|c|c|c|c|c|}
\hline \multicolumn{8}{|c|}{ AVALIAÇÃO DO RISCO DE VIÉS } \\
\hline \multicolumn{8}{|c|}{ FERRAMENTAS DA COLABORAÇÃO COCHRANE PARA AVALIAR O RISCO DE VIÉS } \\
\hline \multirow{2}{*}{$\begin{array}{l}\text { AUTO, ANO E } \\
\text { LOCAL DO } \\
\text { ESTUDO }\end{array}$} & \multicolumn{2}{|c|}{ VIÉS DE SELEÇÃO } & \multirow{2}{*}{$\begin{array}{c}\text { VIÉS DE } \\
\text { DESEMPENHO } \\
\text { CEGAMENTO DOS } \\
\text { PARTICIPANTES E } \\
\text { PESSOAL }\end{array}$} & \multirow{2}{*}{$\begin{array}{c}\text { VIÉS DE } \\
\text { DETECÇÃO } \\
\text { CEGAMENTO DA } \\
\text { AVALIAÇÃO DOS } \\
\text { RESULTADOS }\end{array}$} & \multirow{2}{*}{$\begin{array}{c}\text { VIÉS DE ATRITO } \\
\text { DADOS DOS } \\
\text { RESULTADOS } \\
\text { INCOMPLETOS }\end{array}$} & \multirow{2}{*}{$\begin{array}{c}\text { VIÉS DE } \\
\text { COMUNICAÇÃO } \\
\text { RELATÓRIOS } \\
\text { SELETIVOS }\end{array}$} & \multirow{2}{*}{$\begin{array}{c}\text { OUTRO VIÉS } \\
\text { OUTRAS } \\
\text { FONTES DE } \\
\text { VIÉS }\end{array}$} \\
\hline & $\begin{array}{l}\text { GERAÇÃO DE } \\
\text { SEQUENCIA } \\
\text { ALEATÓRIA }\end{array}$ & $\begin{array}{c}\text { OCULTAÇÃO DA } \\
\text { ALOCAÇÃO }\end{array}$ & & & & & \\
\hline $\begin{array}{c}\text { Spillane et al. } \\
\text { (2012) } \\
\text { (USA) }\end{array}$ & $\begin{array}{l}\text { - Os sujeitos } \\
\text { foram convocados } \\
\text { por telefone ou por } \\
\text { e-mail e somente } \\
\text { participaram os } \\
\text { que atendiam aos } \\
\text { critérios adotados }\end{array}$ & $\begin{array}{l}\text { - O suplemento e o } \\
\text { placebo tinham a } \\
\text { mesma aparência } \\
\text { nas cápsulas. }\end{array}$ & $\begin{array}{l}\text { - Foi citado que } \\
\text { foi duplo cego, } \\
\text { mas não foi } \\
\text { fornecido o } \\
\text { detalhamento }\end{array}$ & $\begin{array}{l}\text { - Informação } \\
\text { insuficiente para } \\
\text { permitir o } \\
\text { julgamento }\end{array}$ & $\begin{array}{c}\text { - Iniciou com } 22 \\
\text { e terminou com } \\
19 \\
\text { - Esses dropouts } \\
\text { não foram } \\
\text { investigados. }\end{array}$ & $\begin{array}{c}\text { - Não há } \\
\text { sugestão de } \\
\text { dados não } \\
\text { apresentados }\end{array}$ & $\begin{array}{l}\text { - O estudo } \\
\text { parece estar } \\
\text { livre de outras } \\
\text { fontes de viés }\end{array}$ \\
\hline & Baixo risco & Baixo risco & Pouco claro & Pouco claro & Baixo risco & Baixo risco & Baixo risco \\
\hline $\begin{array}{l}\text { Areces et al. } \\
\qquad(2014) \\
\text { (SPAIN) }\end{array}$ & $\begin{array}{l}\text { - Informação } \\
\text { insuficiente }\end{array}$ & $\begin{array}{c}\text { - Os atletas de } \\
\text { BCAA receberam } \\
\text { pelo menos } 1 \\
\text { semana antes da } \\
\text { corrida, um } \\
\text { recipiente opaco } \\
\text { sem marca com } 35 \mathrm{~g} \\
\text { de BCAA puro e } \\
\text { uma colher } \\
\text { etiquetada para } \\
\text { uma dose de } 5 \mathrm{~g} \text {. } \\
\text { - Os atletas do } \\
\text { grupo controle } \\
\text { receberam o } \\
\text { mesmo recipiente, } \\
\text { mas com um } \\
\text { placebo isocalórico } \\
\text { e isovolumétrico. }\end{array}$ & $\begin{array}{l}\text { - Estudo duplo- } \\
\text { cego, placebo } \\
\text { controlado e } \\
\text { randomizado. }\end{array}$ & $\begin{array}{l}\text { - Informação } \\
\text { insuficiente para } \\
\text { permitir o } \\
\text { julgamento }\end{array}$ & $\begin{array}{l}\text { - Iniciou com } 50 \\
\text { e finalizou com } \\
\quad 46 . \\
\text { - A análise de } \\
\text { intenção de } \\
\text { tratar foi } \\
\text { utilizada para o } \\
\text { número de } \\
\text { participantes de } \\
\text { cada grupo que } \\
\text { terminaram a } \\
\text { corrida. } \\
\text { - Os dados em } \\
\text { falta foram } \\
\text { colocados } \\
\text { utilizando } \\
\text { métodos } \\
\text { adequados. }\end{array}$ & $\begin{array}{l}\text { - O protocolo do } \\
\text { estudo está } \\
\text { disponível e } \\
\text { todos os } \\
\text { resultados pré- } \\
\text { especificados } \\
\text { (primário e } \\
\text { secundário) que } \\
\text { são de interesse } \\
\text { na revisão foram } \\
\text { relatados na } \\
\text { forma pré- } \\
\text { especificada. }\end{array}$ & $\begin{array}{l}\text { - O estudo } \\
\text { parece estar } \\
\text { livre de outras } \\
\text { fontes de viés }\end{array}$ \\
\hline & Pouco claro & Pouco claro & Pouco claro & Pouco claro & Baixo risco & Baixo risco & Baixo risco \\
\hline
\end{tabular}


Tabela 4 - Sumário da avaliação do risco de viés (cont.)

\begin{tabular}{|c|c|c|c|c|c|c|c|}
\hline \multicolumn{8}{|c|}{ AVALIAÇÃO DO RISCO DE VIÉS } \\
\hline \multicolumn{8}{|c|}{ FERRAMENTAS DA COLABORAÇÃo COCHRANE PARA AVALIAR O RISCO DE VIÉS } \\
\hline \multirow{2}{*}{$\begin{array}{c}\text { AUTO, ANO E } \\
\text { LOCAL DO } \\
\text { ESTUDO }\end{array}$} & \multicolumn{2}{|c|}{ VIÉS DE SELEÇÃO } & \multirow{2}{*}{$\begin{array}{c}\text { VIÉS DE } \\
\text { DESEMPENHO } \\
\text { CEGAMENTO DOS } \\
\text { PARTICIPANTES E } \\
\text { PESSOAL }\end{array}$} & \multirow{2}{*}{$\begin{array}{c}\text { VIÉS DE } \\
\text { DETECÇÃO } \\
\text { CEGAMENTO DA } \\
\text { AVALIAÇÃO DOS } \\
\text { RESULTADOS }\end{array}$} & \multirow{2}{*}{$\begin{array}{c}\text { VIÉS DE ATRITO } \\
\text { DADOS DOS } \\
\text { RESULTADOS } \\
\text { INCOMPLETOS }\end{array}$} & \multirow{2}{*}{$\begin{array}{c}\text { VIÉS DE } \\
\text { COMUNICAÇÃO } \\
\text { RELATÓRIOS } \\
\text { SELETIVOS }\end{array}$} & \multirow{2}{*}{$\begin{array}{c}\text { OUTRO VIÉS } \\
\text { OUTRAS } \\
\text { FONTES DE } \\
\text { VIÉS }\end{array}$} \\
\hline & $\begin{array}{l}\text { GERAÇÃO DE } \\
\text { SEQUENCIA } \\
\text { ALEATÓRIA }\end{array}$ & $\begin{array}{c}\text { OCULTAÇÃO DA } \\
\text { ALOCAÇÃO }\end{array}$ & & & & & \\
\hline $\begin{array}{c}\text { Leahy \& Pintauro } \\
\text { (2013) } \\
\text { (USA) }\end{array}$ & $\begin{array}{l}\text { - Os indivíduos } \\
\text { foram designados } \\
\text { aleatoriamente para } \\
\text { o grupo de BCAA } \\
\text { ou placebo. }\end{array}$ & $\begin{array}{c}\text {-O placebo foi } \\
\text { formulado para } \\
\text { corresponder tanto } \\
\text { ao gosto quanto à } \\
\text { cor do suplemento } \\
\text { de teste. } \\
\text { - Ambos foram } \\
\text { fornecidos aos } \\
\text { participantes na } \\
\text { forma de pó, pré- } \\
\text { medido em } 5 \text { tubos } \\
\text { de teste de plástico } \\
\text { não marcado. } \\
\text { - Os tubos tinham } \\
\text { aparência idêntica, } \\
\text { mas não eram } \\
\text { numerados } \\
\text { sequencialmente. }\end{array}$ & $\begin{array}{l}\text { - Randomizado, } \\
\text { controlado, duplo- } \\
\text { cego cruzado. } \\
\text { - Informação } \\
\text { insuficiente para } \\
\text { permitir um } \\
\text { julgamento. }\end{array}$ & $\begin{array}{l}\text { - Informação } \\
\text { insuficiente para } \\
\text { permitir o } \\
\text { julgamento }\end{array}$ & $\begin{array}{c}\text { - Iniciou com } 20 \\
\text { e terminou com } \\
20\end{array}$ & $\begin{array}{l}\text { - O protocolo do } \\
\text { estudo está } \\
\text { disponível e } \\
\text { todos os } \\
\text { resultados pré- } \\
\text { especificados } \\
\text { (primário e } \\
\text { secundário) que } \\
\text { são de interesse } \\
\text { na revisão foram } \\
\text { relatados na } \\
\text { forma pré- } \\
\text { especificada. }\end{array}$ & $\begin{array}{l}\text { - O estudo } \\
\text { parece estar } \\
\text { livre de } \\
\text { outras fontes } \\
\text { de viés }\end{array}$ \\
\hline & Pouco claro & Pouco claro & Pouco claro & Pouco claro & Baixo risco & Baixo risco & Baixo risco \\
\hline
\end{tabular}


A extração dos dados foi realizada em uma planilha onde foram descritos tipo de desfecho; sexo e grau de condicionamento dos participantes; idade dos participantes; desenho do estudo; descrição do suplemento e placebo; tempo de intervenção; desfecho e medidas; tamanho da amostra inicial e final; principais resultados e conclusões; risco de viés (Tabela 5). 
Tabela 5 - Sumário da coleta de dados do estudo.

\begin{tabular}{|c|c|c|c|c|c|c|c|}
\hline NÚMERO & AUTOR E ANO & PAÍS & $\begin{array}{c}\text { TIPO DE } \\
\text { DESFECHO }\end{array}$ & $\begin{array}{l}\text { SEXO DOS PARTICIPANTES E } \\
\text { GRAU DE } \\
\text { CONDICIONAMENTO FÍSICO }\end{array}$ & $\begin{array}{l}\text { IDADE DOS } \\
\text { PARTICIPANTES }\end{array}$ & $\begin{array}{l}\text { DESENHO DO } \\
\text { ESTUDO }\end{array}$ & $\begin{array}{c}\text { DESCRIÇÃO DO SUPLEMENTO E } \\
\text { DO PLACEBO }\end{array}$ \\
\hline 1 & $\begin{array}{l}\text { Apró W.; } \\
\text { Blomstrand E. } \\
(2010)\end{array}$ & - Suécia & $\begin{array}{l}\text { - Massa } \\
\text { muscular }\end{array}$ & $\begin{array}{l}\text { - } 4 \text { homens e } 5 \text { mulheres } \\
\text { - Praticavam atividades } \\
\text { recreacionais (corrida, } \\
\text { bicicleta e acrobacias), } \\
1 \text { ou } 2 \text { x /semana. }\end{array}$ & $\begin{array}{l}\text { - Homens: } 27 \pm 1 \text { ano e } \\
\text { - Mulheres: } 24 \pm 2 \text { anos }\end{array}$ & $\begin{array}{l}\text { - Randomizado } \\
\text { - Duplo cego } \\
\text { cruzado }\end{array}$ & $\begin{array}{l}\text { - } 150 \text { mL de uma solução } \\
\text { contendo } 45 \% \text { leucina, } 30 \% \\
\text { valina e } 25 \% \text { isoleucina ou água } \\
\text { aromatizada. } \\
\text { - as duas bebidas foram } \\
\text { aromatizadas com aroma de limão } \\
\text { contendo sais e adoçantes. } \\
\text { artificiais, sendo indistinguíveis } \\
\text { no sabor. }\end{array}$ \\
\hline 2 & $\begin{array}{l}\text { Borgenvik et } \\
\text { al. }(2011)\end{array}$ & - Suécia & $\begin{array}{l}\text { - Massa } \\
\text { muscular }\end{array}$ & $\begin{array}{l}\text { - } 5 \text { homes e } 2 \text { mulheres } \\
\text { - Praticavam atividades } \\
\text { recreativas } 1 \mathrm{ou} \\
2 \mathrm{x} / \text { semana, sem exercícios } \\
\text { de resistência. }\end{array}$ & $\begin{array}{l}\text { - Homens e mulheres: } \\
27 \pm 2 \text { anos }\end{array}$ & $\begin{array}{l}\text { - Randomizado } \\
\text { - Duplo cego } \\
\text { cruzado }\end{array}$ & $\begin{array}{l}\text { - } 150 \mathrm{ml} \text { de uma mistura de } \\
\text { BCAA’s ( } 45 \% \text { leucina, } 30 \% \\
\text { valina e } 25 \% \text { isoleucina) em água } \\
\text { aromatizada ou só água } \\
\text { aromatizada. } \\
\text { - As duas bebidas eram sabor } \\
\text { limão com sais e adoçantes, } \\
\text { indistinguíveis no sabor. }\end{array}$ \\
\hline 3 & $\begin{array}{l}\text { Ferreira et al. } \\
(2014)\end{array}$ & - USA & $\begin{array}{l}\text { - Massa } \\
\text { muscular }\end{array}$ & $\begin{array}{l}\text { - } 27 \text { homens ativos } \\
\text { - Sem treinamentos } \\
\text { Consistentes. }\end{array}$ & - 18 a 30 anos & $\begin{array}{l}\text { - Randomizado } \\
\text { - Duplo cego }\end{array}$ & $\begin{array}{l}\text { - } \mathrm{CHO}=1,4 \mathrm{~g} \text { açúcares (dextrose, } \\
\text { frutose e sacarose). } \\
\text { - } \mathrm{BCAA}=50 \% \text { leucina, } 25 \% \\
\text { isoleucina e } 25 \% \text { valina. } \\
\text { - } \mathrm{PLC}=\text { solução flavorizada. }\end{array}$ \\
\hline
\end{tabular}


Tabela 5 - Sumário da coleta de dados do estudo (cont.)

\begin{tabular}{|c|c|c|c|c|c|}
\hline NÚMERO & $\begin{array}{c}\text { TEMPO DE } \\
\text { INTERVENÇÃo }\end{array}$ & $\begin{array}{l}\text { DESFECHOS E } \\
\text { MEDIDAS }\end{array}$ & $\begin{array}{c}\text { TAMANHO } \\
\text { AMOSTRAL INICIAL } \\
\text { E FINAL }\end{array}$ & PRINCIPAIS RESULTADOS E CONCLUSÕES & $\begin{array}{l}\text { RISCO DE } \\
\text { VIÉS }\end{array}$ \\
\hline 1 & $\begin{array}{l}\text { - Em repouso antes } \\
\text { do aquecimento } \\
\text { - Antes de começar o } \\
\text { exercício de } \\
\text { resistência } \\
\text { - Após a quarta } \\
\text { sessão( 20 minutos } \\
\text { de exercício) e após } \\
\text { o exercício } \\
\text { - Após } 15 \text { ' e } 45 \text { ' de r } \\
\text { recuperação }\end{array}$ & $\begin{array}{l}\text { - mTOR, } \\
\text { - p70S6k, rpS6 } \\
\text { - alongamento } \\
\text { eucariótico } \\
\text { - insulina. }\end{array}$ & - 9 & $\begin{array}{l}\text { - A ingestão de BCAA e exercício de resistência aumentam mais a fosforilação de } \\
\text { p70S6k do que a soma dos dois, indicando um efeito sinérgico destes dois } \\
\text { estímulos sobre p70S6k. } \\
\text { - A fosforilação de mTOR aumentou com a ingestão de BCAA. } \\
\text { - A fosforilação de mTOR, foi alterada de forma semelhante tanto no músculo em } \\
\text { repouso como no exercício, sugerindo uma regulação sistêmica em vez de uma } \\
\text { contração induzida destas enzimas. }\end{array}$ & $\begin{array}{l}\text { - Pouco } \\
\text { claro }\end{array}$ \\
\hline 2 & $\begin{array}{l}\text { - Em repouso antes } \\
\text { do aquecimento } \\
\text { - Antes de começar o } \\
\text { exercício de } \\
\text { resistência } \\
\text { - Durante e } \\
\text { imediatamente após } \\
\text { o exercício } \\
\text { - Após } 15 \text { ' e } 45 \text { ' de } \\
\text { recuperação }\end{array}$ & $\begin{array}{l}\text { - Glicose, lactato } \\
\text { - Fenilalanina } \\
\text { - Aminoácidos } \\
\text { - Akt, mTor } \\
\text { - p70s6k } \\
\text { - MAFbx mRNA } \\
\text { - MuRF-1 } \\
\text { mRNA. }\end{array}$ & - 7 & $\begin{array}{l}\text { - A suplementação com BCAA reduz a expressão do MAFbx mRNA no músculo } \\
\text { em repouso e no exercício e preveniu o aumento na expressão total da proteína } \\
\text { de outra ligase de ubiquitina, MuRF-1. } \\
\text { - O exercício resistido causou elevação de MuRF-1 mRNA e de proteína total. } \\
\text { - Estas observações, juntamente com o BCAA induzindo a fosforilação p70S6k, } \\
\text { fornecem suporte adicional de que o BCAA tem um efeito anabólico no } \\
\text { músculo esquelético humano, um efeito que parece ser semelhante no músculo } \\
\text { em repouso e em exercício. }\end{array}$ & $\begin{array}{l}\text { Pouco } \\
\text { claro }\end{array}$ \\
\hline 3 & $\begin{array}{l}\text { - Na retirada do } \\
\text { sangue em jejum } \\
\text { - } 10 \text { minutos pré- } \\
\text { exercício } \\
\text { - } 5 \text { minutos pós } \\
\text { exercício }\end{array}$ & $\begin{array}{l}\text { - Altura, massa } \\
\text { corporal } \\
\text { - Glicose sérica } \\
\text { - Insulina } \\
\text { - Fosfoproteínas } \\
\text { do } \\
\text { músculo } \\
\text { esquelético,IRS- } \\
1 \\
\text { - mTOR, p70Sk6, } \\
\text { Akt, 4E-BP1. }\end{array}$ & - 27 & $\begin{array}{l}\text { - O RE, mas não a ingestão de CHO e/ou BCAA, está associada à ativação do } \\
\text { mTOR. IRS-1 e Akt. } \\
\text { - A suplementação de CHO atua sobre a fosforilação de Akt, independente de } \\
\text { BCAA e RE. Não está claro se MPS é realmente impactada pela co-ingestão de } \\
\text { CHO e BCAA, quando comparado com CHO sozinho. } \\
\text { - A ingestão de CHO ou CHO+BCAA aumenta a fosforilação de IRS-1, mas não } \\
\text { de mTOR, Akt e p70S6k. } \\
\text { - A co-ingestão de BCAA e CHO não aumentam a indução de RE e nem } \\
\text { aumentam os marcadores de sinalização de músculo esquelético indicativo de } \\
\text { MPS quando comparado com CHO sozinho. }\end{array}$ & $\begin{array}{l}\text { - Baixo } \\
\text { risco }\end{array}$ \\
\hline
\end{tabular}


Tabela 5 - Sumário da coleta de dados do estudo (cont.)

\begin{tabular}{|c|c|c|c|c|c|c|c|}
\hline NÚMERO & AUTOR E ANO & País & $\begin{array}{l}\text { TIPO DE } \\
\text { DESFECHO }\end{array}$ & $\begin{array}{c}\text { SEXO DOS PARTICIPANTES } \\
\text { E GRAU DE } \\
\text { CONDICIONAMENTO } \\
\text { FÍSICO } \\
\end{array}$ & $\begin{array}{c}\text { IDADE DOS } \\
\text { PARTICIPANTES }\end{array}$ & $\begin{array}{l}\text { DESENHO DO } \\
\text { ESTUDO }\end{array}$ & $\begin{array}{c}\text { DESCRIÇÃO DO SUPLEMENTO E } \\
\text { DO PLACEBO }\end{array}$ \\
\hline 4 & $\begin{array}{l}\text { Tatpat et al. } \\
(2010)\end{array}$ & - USA & - Performance & $\begin{array}{l}\text { - } 12 \text { jovens sedentários e } \\
12 \text { idosos sedentários. }\end{array}$ & $\begin{array}{l}\text { - 65-80 anos } \\
-18-30 \text { anos }\end{array}$ & $\begin{array}{l}\text { - Randomizado } \\
\text { Cruzado }\end{array}$ & $\begin{array}{l}\text { - Infusão de BCAA (Branchamin } \\
4 \%) \text {. } \\
\text { - O volume de solução salina } \\
\text { ( } 0,9 \% \text { de salina normal) foi } \\
\text { equivalente à da solução de } \\
\text { BCAA. }\end{array}$ \\
\hline 5 & $\begin{array}{l}\text { Spillane et al. } \\
\text { (2012) }\end{array}$ & - USA & $\begin{array}{l}\text {-Massa } \\
\text { muscular } \\
\text { - Desempenho } \\
\text { muscular } \\
\end{array}$ & $\begin{array}{l}\text { - } 22 \text { indivíduos. } \\
\text { - Não treinados. }\end{array}$ & $\begin{array}{l}\text { - Placebo: } \\
\text { 20,4 } \pm 1,33 \text { anos } \\
\text { - BCAA: } \\
21,3 \pm 2,36 \text { anos } \\
\end{array}$ & - Duplo cego & $\begin{array}{l}\text { - Cápsulas contendo 9g de BCAA } \\
\text { (leucina } 4,5 \mathrm{~g} \text {, isoleucina } 2,25 \mathrm{~g} \text { e } \\
\text { valina } 2,25 \mathrm{G} \text { ). } \\
\text { - 9g de placebo (goma guar). }\end{array}$ \\
\hline 6 & $\begin{array}{l}\text { Howatson et } \\
\text { al. }(2012)\end{array}$ & - UK & $\begin{array}{l}\text { - Dano } \\
\text { muscular }\end{array}$ & $\begin{array}{l}\text { - } 12 \text { indivíduos. } \\
\text { - Jogadores de hugby e } \\
\text { futebol }\end{array}$ & - $23 \pm 2$ anos & $\begin{array}{l}\text { - Randomizado } \\
\text { - Duplo-cego } \\
\text { - Placebo } \\
\text { controlado. }\end{array}$ & $\begin{array}{l}\text { - BCAA 2:1:1 (5g leucina, } 2,5 \mathrm{~g} \\
\text { isoleucina e 2,5g valina). } \\
\text { - Placebo: adoçante artificial à } \\
\text { base de aspartame. }\end{array}$ \\
\hline
\end{tabular}


Tabela 5 - Sumário da coleta de dados do estudo (cont.)

\begin{tabular}{|c|c|c|c|c|c|}
\hline NÚMERO & $\begin{array}{c}\text { TEMPO DE } \\
\text { INTERVENÇÃO }\end{array}$ & $\begin{array}{l}\text { DESFECHOS E } \\
\text { MEDIDAS }\end{array}$ & $\begin{array}{c}\text { TAMANHO } \\
\text { AMOSTRAL INICIAL } \\
\text { E FINAL } \\
\end{array}$ & PRINCIPAIS RESULTADOS E CONCLUSÕES & $\begin{array}{l}\text { RISCO DE } \\
\text { VIÉS }\end{array}$ \\
\hline 4 & $\begin{array}{l}\text { - A infusão de } \\
\text { BCAA foi } \\
\text { administrada } \\
0,13 \mathrm{ml} / \mathrm{kg} \text { de massa } \\
\text { livre de gordura por } \\
\text { hora, por } 30 \text { minutos } \\
\text { - Reduzida para } \\
0,043 \mathrm{ml} / \mathrm{kg} \text { de massa } \\
\text { livre de gordura por } \\
\text { hora de } 30 \text { a } 480 \\
\text { minutos }\end{array}$ & $\begin{array}{l}\text {-Valina, leucina, } \\
\text { isoleucina } \\
\text { - insulina, } \\
\text { glicose, } \\
\text { ácidos graxos } \\
\text { livres } \\
\text { - C-peptídeo } \\
\text { - Testosterona } \\
\text { sérica } \\
\text { - MAPR, MtDNA } \\
\text { - Glucagon }\end{array}$ & -24 & $\begin{array}{l}\text { - A infusão de BCAA aumenta o MAPR em jovens quando comparados com } \\
\text { solução salina, mas não em idosos. Também aumenta concentrações plasmáticas } \\
\text { de insulina, C-peptídeo e glucagon nos jovens e idosos. } \\
\text { - As variações na resposta fisiológica foram associadas com o envelhecimento. } \\
\text { - A abundância de mtDNA muscular foi menor nos idosos no que nos mais jovens } \\
\text { e não foi afetada pela infusão de BCAA. } \\
\text { - Outros estudos são necessários para examinar o mecanismo exato pelo qual os } \\
\text { BCAAs aumentam o MAPR em jovens, mas não nos idosos. }\end{array}$ & - Baixo risco \\
\hline 5 & $\begin{array}{l}\text { - Metade da dose (6 } \\
\text { cápsulas) foi } \\
\text { ingerida } 30 \text { ' antes } \\
\text { do exercício } \\
\text { - A outra metade foi } \\
\text { ingerida } 30 \text { ' depois } \\
\text { de cada exercício } \\
\text { - Ingeridos } 4 x \text { por } \\
\text { semana, somente } \\
\text { nos dias de } \\
\text { exercício. }\end{array}$ & $\begin{array}{l}\text { - Composição } \\
\text { corporal } \\
\text { - Força superior e } \\
\text { inferior do corpo } \\
\text { - Resistência do } \\
\text { músculo superior } \\
\text { e } \\
\text { resistência } \\
\text { inferior } \\
\text { do corpo. }\end{array}$ & $\begin{array}{l}\text { - Inicial =22 } \\
\text { - Final: } \\
\text { Placebo = } 9 \\
\text { BCAA = } 10\end{array}$ & $\begin{array}{l}\text { - } 8 \text { semanas com BCAA não tiveram efeito na composição corporal e } \\
\text { desempenho muscular em conjunto com treinamento de resistência pesada. } \\
\text { - Ambos os grupos mostraram resultados semelhantes, indicando que as melhoras } \\
\text { foram devido ao treinamento de resistência. Essas melhoras eram esperadas, } \\
\text { porque os participantes não eram treinados. } \\
\text { - Apesar das pequenas diferenças encontradas na composição corporal no BCAA, } \\
\text { em relação ao placebo, essas diferenças não foram significativas. } \\
\text { - O treinamento de resistência pesada combinada com 9g de BCAA ingeridos } 4 \\
\text { dias/semana, antes e depois dos exercícios, não tem efeito sobre a composição e } \\
\text { desempenho muscular. }\end{array}$ & - Pouco claro \\
\hline 6 & $\begin{array}{l}\text { - } 10 \mathrm{~g}, 2 \mathrm{x} \text { ao dia } \\
\text { (manhã e tarde) } \\
\text { - Após um jejum } \\
\text { durante a noite, } \\
\text { tomaram mais } 20 \mathrm{~g} \\
\text { - } 1 \text { hora antes dos } \\
\text { exercícios e } \\
\text { imediatamente após }\end{array}$ & $\begin{array}{l}\text { - Creatina quinase } \\
\text { - Dor muscular } \\
\text { (DOMS) } \\
\text { - Contração } \\
\text { voluntária } \\
\text { máxima } \\
\text { (MVC) } \\
\text { - Salto vertical } \\
\text { (VJ) } \\
\text { - Circunferência } \\
\text { do membro. }\end{array}$ & - 12 & $\begin{array}{l}\text { - A CK começou mais baixa no grupo de BCAA. Após } 24 \text { h pós-exercício, atingiu } \\
\text { um pico para os dois grupos. A dor estava menor } 24-48 \text { h pós-exercício no grupo } \\
\text { do BCAA comparado com placebo. } \\
\text { - MVC mostrou um grande efeito no grupo do BCAA na recuperação da força. } \\
\text { - O BCAA administrado antes e após exercícios de resistência reduz o dano } \\
\text { muscular a acelera a recuperação em indivíduos treinados. } \\
\text { - BCAA proporciona uma maior biodisponibilidade do substrato para melhorar a } \\
\text { síntese proteica e a extensão do dano muscular secundário associado com o } \\
\text { exercício de resistência extenuante. }\end{array}$ & - Baixo risco \\
\hline
\end{tabular}


Tabela 5 - Sumário da coleta de dados do estudo (cont.)

\begin{tabular}{|c|c|c|c|c|c|c|c|}
\hline NÚMERO & AUTOR E ANO & PAÍS & $\begin{array}{c}\text { TIPO DE } \\
\text { DESFECHO }\end{array}$ & $\begin{array}{l}\text { SEXO DOS PARTICIPANTES E } \\
\text { GRAU DE } \\
\text { CONDICIONAMENTO FÍSICO }\end{array}$ & $\begin{array}{l}\text { IDADE DOS } \\
\text { PARTICIPANTES }\end{array}$ & $\begin{array}{l}\text { DESENHO DO } \\
\text { ESTUDO }\end{array}$ & $\begin{array}{c}\text { DESCRIÇÃO DO SUPLEMENTO E } \\
\text { DO PLACEBO }\end{array}$ \\
\hline 7 & $\begin{array}{l}\text { Pertier et al. } \\
(2011)\end{array}$ & - França & $\begin{array}{l}\text { - Performance } \\
\text { - Função } \\
\text { neuromuscular }\end{array}$ & $\begin{array}{l}\text { - } 13 \text { adultos } \\
\text { - Treinados }\end{array}$ & - 29,6 \pm 9,2 anos & $\begin{array}{l}\text { - Randomizado } \\
\text { - Duplo-cego } \\
\text { cruzado } \\
\text { - Placebo } \\
\text { controlado }\end{array}$ & $\begin{array}{l}\text {-Sports drink (SPD) : } 31,6 \mathrm{~g} \\
\text { maltodextrina,24,2g dextrose, } \\
\text { 12,8g frutose, 4g BCAA e } \\
\text { vitaminas. } \\
\text { - Placebo (PLA) : Ácido cítrico e } \\
\text { málico, goma, acesulfame de } \\
\text { potássio, sucralose. }\end{array}$ \\
\hline 8 & $\begin{array}{l}\text { Gualano et al. } \\
\text { (2011) }\end{array}$ & - Brasil & $\begin{array}{l}\text { - Performance } \\
\text { - Oxidação } \\
\text { lipídica. }\end{array}$ & $\begin{array}{l}\text { - } 7 \text { indivíduos } \\
\text { - Fisicamente ativos. }\end{array}$ & - $24 \pm 2$ anos & $\begin{array}{l}\text { - Randomizado } \\
\text { - Duplo-cego } \\
\text { cruzado }\end{array}$ & $\begin{array}{l}\text { - BCAA : cápsulas de } 300 \mathrm{mg}(6 \mathrm{~g}) \\
\text { - Placebo: maltodextrina } 300 \mathrm{mg} \\
(6 \mathrm{~g})\end{array}$ \\
\hline 9 & $\begin{array}{l}\text { Greer et al. } \\
(2011)\end{array}$ & - USA & - Performance & $\begin{array}{l}\text { - } 9 \text { indivíduos } \\
\text { - Não treinados }\end{array}$ & - 21,6 $\pm 3,2$ anos & - Randomizado & $\begin{array}{l}\text { - Placebo: água, sal, aroma limão } \\
\text { e adoçante artificial } \\
\text { - CHO: Gatorade } \\
\text { - BCAA: } 4,8 \mathrm{~g} \text { isoleucina, } 12,2 \mathrm{~g} \\
\text { leucina e } 7,3 \mathrm{~g} \text { valina }\end{array}$ \\
\hline
\end{tabular}


Tabela 5 - Sumário da coleta de dados do estudo (cont.)

\begin{tabular}{|c|c|c|c|c|c|}
\hline NÚMERO & $\begin{array}{c}\text { TEMPO DE } \\
\text { INTERVENÇÃO }\end{array}$ & $\begin{array}{l}\text { DESFECHOS E } \\
\text { MEDIDAS }\end{array}$ & $\begin{array}{c}\text { TAMANHO } \\
\text { AMOSTRAL INICIAL } \\
\text { E FINAL }\end{array}$ & PRINCIPAIS RESULTADOS E CONCLUSÕES & $\begin{array}{l}\text { RISCO DE } \\
\text { VIÉS }\end{array}$ \\
\hline 7 & $\begin{array}{l}\text { - } 15 \text { minutos antes } \\
\text { dos testes } \\
\text { - Imediatamente } \\
\text { antes do } \\
\text { aquecimento } \\
\text { - Foram fornecidos } \\
250 \mathrm{ml} \text { de bebida a } \\
\text { cada } 15 \text { minutos. }\end{array}$ & $\begin{array}{l}\text { - Total da distância } \\
\text { percorrida } \\
\text { - Glicemia, lactato } \\
\text { - Função } \\
\text { neuromuscular. } \\
\text {-VO2,frequência } \\
\text { cardíaca. } \\
\text { - Taxa de esforço } \\
\text { percebido. }\end{array}$ & - $13 / 11$ & $\begin{array}{l}\text { - Comparado com o placebo, a ingestão do SPD aumentou a performance, } \\
\text { mantendo a glicemia e atenuando a fadiga central, a taxa da fadiga periférica, e a } \\
\text { taxa de esforço percebido. } \\
\text { - Contração máxima voluntária, VO } 2 \text { e frequência cardíaca não tiveram } \\
\text { diferenças nas duas condições. } \\
\text { - A ingestão combinada de CHOs, BCAA e cafeína, aumentou a performance } \\
\text { cerca de } 2 \% \text { durante } 2 \mathrm{~h} \text { de corrida em esteira. }\end{array}$ & $\begin{array}{l}\text { - Pouco } \\
\text { claro }\end{array}$ \\
\hline 8 & $\begin{array}{l}\text { - } 3 \text { dias antes dos } \\
\text { testes de } \\
\text { exercícios } \\
\text { exaustivos, } \\
\text { inclusive } \\
\text { nos dias dos testes. } \\
\text { - Período de } \\
\text { washout } \\
\text { de } 7 \text { dias }\end{array}$ & $\begin{array}{l}\text { - Relação da troca } \\
\text { respiratória (RER) } \\
\text { - Glicose,ácidos } \\
\text { graxos livres. } \\
\text { - Cetonas, lactato }\end{array}$ & $\cdot 7$ & $\begin{array}{l}\text { - A suplementação de BCAA promoveu um grande aumento no tempo de } \\
\text { exaustão quando comparado com placebo e diminuiu RER também. } \\
\text { - A glicose aumentou após a suplementação de BCAA comparada com o placebo. } \\
\text { - Não houve diferenças significativas nas concentrações de ácidos graxos livres, } \\
\text { cetonas e lactato em ambos os grupos. } \\
\text { - A suplementação de BCAA aumenta a resistência à fadiga e aumenta a oxidação } \\
\text { lipídica durante o exercício em indivíduos com depleção de glicogênio. }\end{array}$ & $\begin{array}{l}\text { - Pouco } \\
\text { claro }\end{array}$ \\
\hline 9 & $\begin{array}{l}\text { - Administradas } 5 \\
\text { minutos antes do } \\
\text { início do exercício } \\
\text { - Após } 60 \text { minutos. }\end{array}$ & $\begin{array}{l}\text { - } \text { Glicose,BCAA } \\
\text { - Esforço percebido } \\
\text { (RPE) } \\
\text { - VO } \\
\text { - Teste de } \\
\text { performance }\end{array}$ & - 9 & $\begin{array}{l}\text { - Ciclistas com CHO percorreram uma distância maior do que o placebo, já com } \\
\text { BCAA não houve diferença em nenhum dos grupos. } \\
\text { - A suplementação com BCAA reduziu o RPE aos } 75 \text { e } 90 \text { minutos, comparado } \\
\text { com o placebo. } \\
\text { - As concentrações de BCAA no pós exercício, reduziram com CHO e placebo, já } \\
\text { com BCAA, houve um aumento acentuado do mesmo. } \\
\text { - A suplementação de BCAA atenua RPE mas não afeta a performance durante } \\
\text { exercício de endurance prolongado. A redução no RPE não foi estatisticamente } \\
\text { significante. } \\
\text { - A performance somente aumentou com o CHO. A combinação de BCAA com } \\
\text { CHO garante um melhor resultado em exercícios aeróbicos. }\end{array}$ & $\begin{array}{l}\text { Pouco } \\
\text { claro }\end{array}$ \\
\hline
\end{tabular}


Tabela 5 - Sumário da coleta de dados do estudo (cont.)

\begin{tabular}{|c|c|c|c|c|c|c|c|}
\hline NÚMERO & AUTOR E ANO & PAÍS & $\begin{array}{c}\text { TIPO DE } \\
\text { DESFECHO }\end{array}$ & $\begin{array}{l}\text { SEXO DOS PARTICIPANTES E } \\
\text { GRAU DE } \\
\text { CONDICIONAMENTO FÍSICO }\end{array}$ & $\begin{array}{c}\text { IDADE DOS } \\
\text { PARTICIPANTES }\end{array}$ & $\begin{array}{l}\text { DESENHO DO } \\
\text { ESTUDO }\end{array}$ & $\begin{array}{c}\text { DESCRIÇÃO DO SUPLEMENTO E } \\
\text { DO PLACEBO }\end{array}$ \\
\hline 10 & $\begin{array}{l}\text { Areces et al. } \\
(2014)\end{array}$ & - Spain & - Performance & - 7 mulheres Atletas & $\begin{array}{l}\text { - } \text { BCAA : } \\
\text { 41,9 } \pm 8,1 \text { anos } \\
\text { - Placebo: } \\
\quad 40,9 \pm 6,8 \text { anos }\end{array}$ & $\begin{array}{l}\text { - Randomizado } \\
\text { - Duplo cego } \\
\text { - Placebo } \\
\text { controlado }\end{array}$ & $\begin{array}{l}\text { 5g BCAA puro (1:0.5:0.5 de } \\
\text { leucina, isoleucina, valina) e } \\
\text { uma colher etiquetada de } 0,5 \mathrm{~g} \\
\text { placebo ( } 1: 1 \text { celulose:dextrose) }\end{array}$ \\
\hline 11 & $\begin{array}{l}\text { Leahy and } \\
\text { Pintauro } \\
(2013)\end{array}$ & - USA & - Performance & $\begin{array}{l}\text { - Homens }(\mathrm{n}=9) \\
\text { - Mulheres }(\mathrm{n}=11) \\
\text { - } \text { Participantes relativamente } \\
\text { inativos }\end{array}$ & $\begin{array}{l}\text { - Homens: } \\
\text { 22,1 } \pm 2,3 \text { anos } \\
\text { - Mulheres: } \\
\text { 21,0 } \pm 1,7 \text { anos }\end{array}$ & $\begin{array}{l}\text { - Randomizado } \\
\text { Controlado } \\
\text { - Duplo-cego } \\
\text { cruzado }\end{array}$ & $\begin{array}{l}\text { - 1,22g de BCAA: leucina, } \\
\text { isoleucina e valina, } 5,6 \mathrm{~g} \text { de } \\
\text { dextrose, vitaminas e minerais } \\
\text { - Placebo: formulado para } \\
\text { corresponder à cor e sabor do } \\
\text { suplemento. Ácido cítrico, } \\
\text { potássio e citrato de sódio, } \\
\text { aspartame , óxido de magnésio, } \\
\text { aroma, suco de limão, } \\
\text { acesulfame de potássio }\end{array}$ \\
\hline
\end{tabular}


Tabela 5 - Sumário da coleta de dados do estudo (cont.)

\begin{tabular}{|c|c|c|c|c|c|}
\hline NÚMERO & $\begin{array}{c}\text { TEMPO DE } \\
\text { INTERVENÇÃO }\end{array}$ & $\begin{array}{l}\text { DESFECHOS E } \\
\text { MEDIDAS }\end{array}$ & $\begin{array}{c}\text { TAMANHO } \\
\text { AMOSTRAL INICIAL } \\
\text { E FINAL } \\
\end{array}$ & PRINCIPAIS RESULTADOS E CONCLUSÕES & $\begin{array}{l}\text { RISCO DE } \\
\text { VIÉS }\end{array}$ \\
\hline 10 & $\begin{array}{l}\text { - } 1 \text { semana antes da } \\
\text { corrida }\end{array}$ & $\begin{array}{l}\text { - Poder muscular } \\
\text { da perna, força do } \\
\text { músculo da perna, } \\
\text { velocidade do } \\
\text { músculo da perna } \\
\text { - Teste de salto } \\
\text { - Força máxima do } \\
\text { punho, massa } \\
\text { corporal, taxa de } \\
\text { percepção de } \\
\text { exaustão, dor no } \\
\text { músculo da perna } \\
\text { - Tempo de corrida } \\
\text { - Mioglobina, } \\
\text { proteína, cetona. }\end{array}$ & - 50/46 & $\begin{array}{l}\text { - Em comparação com o grupo placebo, os atletas suplementados com BCAA não } \\
\text { melhoraram o tempo de corrida durante a competição e não houve reduções na } \\
\text { pós-corrida, na força e poder do músculo da perna durante um contra-movimento } \\
\text { no salto. } \\
\text { - Em comparação ao grupo controle, a suplementação de BCAA não alterou o } \\
\text { esforço percebido. }\end{array}$ & $\begin{array}{l}\text { - Pouco } \\
\text { claro }\end{array}$ \\
\hline 11 & $\begin{array}{l}\text { - Intervalo de } 24 \\
\text { horas em } 4 \text { dias. } \\
\text { - Mínimo de } 3 \\
\text { semanas da } \\
\text { competição da } \\
\text { primeira rodada de } \\
\text { administração do } \\
\text { suplemento, os } \\
\text { participantes } \\
\text { retornaram para a } \\
\text { visita } 2 \text { para } \\
\text { executar o mesmo } \\
\text { procedimento } \\
\text { recebido na visita } 1\end{array}$ & $\begin{array}{l}\text { Dor muscular } \\
\text { retardada }\end{array}$ & - 20 & $\begin{array}{l}\text { - } 24 \text { horas pós-exercício, as pontuações da dor muscular relatada foram } 33 \% \\
\text { menores no grupo do suplemento de BCAA comparado com o grupo placebo. } \\
\text { Contudo esses resultados não diferem significativamente do grupo placebo( } \mathrm{P}= \\
0,106) \text {. } \\
\text { - O grau de dor muscular relatado logo após o exercício para ambos os grupos foi } \\
\text { idêntico (BCAA } 2,00 \pm 0,22 \text {, placebo } 1,95 \pm 0,26) \text {, indicando um alto nível de } \\
\text { confiabilidade teste-reteste para a visita } 1 \text { e } 2 \text {. } \\
\text { - Nenhum efeito significativo da suplementação de BCAA versus placebo foi } \\
\text { observado em indivíduos do sexo masculino nem quando os resultados de ambos } \\
\text { os sexos foram analisados em conjunto. } \\
\text { - Houve aumento da síntese de proteínas e recuperação da dor muscular retardada } \\
\text { somente nas mulheres. }\end{array}$ & $\begin{array}{l}\text { - Pouco } \\
\text { claro }\end{array}$ \\
\hline
\end{tabular}


- 5' etapa e $6^{a}$ etapa: Preenchimento das planilhas e reunião de consenso

A planilha de risco de viés (Tabela 4) e a planilha com a extração dos dados (tabela 5) do primeiro pesquisador foi enviada para o segundo pesquisador que preencheu suas planilhas, seguindo os mesmos critérios do primeiro pesquisador.

Foi realizada a reunião de consenso para avaliação do risco de viés dos artigos.

- $7^{a}$ etapa, $8^{a}$ etapa e $9^{a}$ etapa : Avaliação do risco de viés e relatório final

A partir dos estudos inicialmente incluídos $(n=11), 3$ estudos foram classificados com baixo risco de viés e 8 estudos com risco pouco claro. A metodologia, participantes, intervenções e resultados dos estudos incluídos estão relacionados na tabela 4. Ao todo foram envolvidos 191 participantes nos estudos incluídos. A idade dos participantes variou entre 18 a 80 anos. Em 5 artigos os participantes eram atletas ou fisicamente ativos , tinham atividades recreativas em 4 artigos e em 2 artigos eram sedentários. A performance foi avaliada em 6 artigos e em 5, foi avaliada a massa muscular. A dose de BCAA utilizada foi de $1,2 \mathrm{~g}$ até $10 \mathrm{~g}$, sendo que na forma de infusão foi realizada em 1 artigo, na forma de cápsulas em 2 e na forma de pó em 8 artigos. O período da administração foi antes, durante e após os exercícios. Somente em 2 artigos o número inicial de participantes foi diferente do número final.

O resultado final com os artigos que alcançaram ou não os objetivos, apresentaram desfechos opostos ou diferentes e estudos que não encontraram diferenças significativas, encontram-se na tabela 6. Dos estudos incluídos, 05 estudos alcançaram os objetivos de aumento de massa magra e melhora da performance , 02 apresentaram desfechos diferentes aos objetivos e 04 não encontraram nenhum tipo de diferença significativa. 
Tabela 6 - Resultados obtidos a partir das publicações selecionadas para a presente revisão sistemática.

\begin{tabular}{|c|c|c|c|c|}
\hline & $\begin{array}{c}\text { AUTO, ANO E LOCAL DO } \\
\text { ESTUDO }\end{array}$ & $\begin{array}{l}\text { ALCANÇARAM OS OBJETIVOS DE } \\
\text { AUMENTO DE MASSA MAGRA E } \\
\text { REDUÇÃO DE GORDURAE } \\
\text { PERFORMANCE }\end{array}$ & $\begin{array}{c}\text { APRESENTARAM } \\
\text { DESFECHOS OPOSTOS OU } \\
\text { DIFERENTES AOS } \\
\text { OBJETIVOS (POR EXEMPLO, } \\
\text { PERDA DE MASSA MAGRA } \\
\text {,GANHO DE GORDURA) }\end{array}$ & $\begin{array}{l}\text { NÃO ENCONTRARAM } \\
\text { NENHUM TIPO DE } \\
\text { DIFERENÇA SIGNIFICATIVA }\end{array}$ \\
\hline 1 & $\begin{array}{l}\text { Apró; Blomstrand } \\
\text { (2010) } \\
\text { (Suécia) }\end{array}$ & 凶 & & \\
\hline 2 & $\begin{array}{l}\text { Borgenvik et al. } \\
\text { (2011) (Suécia) }\end{array}$ & 凶 & & \\
\hline 3 & $\begin{array}{l}\text { Ferreira et al. (2014) } \\
\text { (USA) }\end{array}$ & & & 凶 \\
\hline 33 & $\begin{array}{l}\text { Tatpat et al. (2010) } \\
\text { (USA) }\end{array}$ & & & 凶 \\
\hline 5 & $\begin{array}{l}\text { Spillane et al. (2012) } \\
\text { (USA) }\end{array}$ & & & 凶 \\
\hline 6 & $\begin{array}{l}\text { Howatson et al. } \\
\text { (2012) } \\
\text { (Reino Unido) }\end{array}$ & 凶 & & \\
\hline 7 & $\begin{array}{l}\text { Peltier et al. (2011) } \\
\text { (França) }\end{array}$ & & 凶 & \\
\hline 8 & $\begin{array}{l}\text { Gualano et al. (2011) } \\
\text { (Brasil) }\end{array}$ & 凶 & & \\
\hline 9 & $\begin{array}{l}\text { Greer et al. (2011) } \\
\text { (USA) }\end{array}$ & & 凶 & \\
\hline 10 & $\begin{array}{l}\text { Areces et al. (2014) } \\
\text { (Espanha) }\end{array}$ & & & 凶 \\
\hline 11 & $\begin{array}{l}\text { Leahy; Pintauro } \\
\text { (2013) } \\
\text { (USA) }\end{array}$ & 凶 & & \\
\hline
\end{tabular}




\section{DISCUSSÃO}

Seguindo todos os critérios de exclusão estabelecidos, dos 196 artigos selecionados, foram excluídos 164, restando 32 artigos. Depois de realizada a busca do artigo completo e sua respectiva leitura, ainda foram excluídos 21 artigos porque o suplemento era associado com outros nutrientes proteicos ou outros aminoácidos. Esta revisão sistemática avaliou o uso do BCAA isolado, diferente de outras revisões que avaliaram o uso de BCAA associado a outros aminoácidos ou proteínas.

Entre os 11 artigos selecionados, 3 estudos foram classificados com baixo risco de viés e 8 estudos com risco pouco claro. Ainda entre esses 11 artigos, 6 avaliaram o uso de BCAA na performance e 5 em relação à massa muscular dos participantes.

\subsection{Massa muscular}

Estudos têm demostrado a importância dos aminoácidos de cadeia ramificada, particularmente a leucina, que atua no metabolismo das proteínas, estimulando a síntese proteica, e diminuindo o catabolismo proteico muscular (BLOMSTRAND et al, 2006). Dreyer et al (2008), demonstraram que o exercício de resistência isolado ou em combinação com suplementos de aminoácidos essenciais e carboidratos, elevam a síntese proteica no músculo e aumentam a sinalização da via mTOR e do p70S6k.

No estudo de Apró et al (2010), 9 adultos realizaram exercício de resistência unilateral em duas sessões separadas por um mês. Os participantes receberam $150 \mathrm{ml}$ de BCAA (45\% de leucina, $30 \%$ de valina e 25\% de isoleucina) em água aromatizada ou só água aromatizada, resultando em um total de $85 \mathrm{mg}$ de $\mathrm{BCAA} / \mathrm{kg}$ de peso corporal. A ingestão foi realizada antes do exercício; após a quarta sessão e após o exercício ;15 e 45 minutos na recuperação. Esse estudo demonstrou que a ingestão de BCAA combinada com o exercício de resistência aumentou a fosforilação de p70S6K, indicando um efeito sinérgico desses dois estímulos. Já a fosforilação do mTOR é aumentada tanto no músculo em repouso como no exercício e não é significativamente influenciada com a ingestão de BCAA. E o aumento da fosforilação de mTOR e p70S6K pareceram ser independentes de Akt, porque não foi observado qualquer efeito nessa enzima. 
Estudo semelhante foi o de Borgenvik at al (2011) onde cada participante ingeriu $150 \mathrm{ml}$ de BCAA (45\% de leucina, $30 \%$ de valina e $25 \%$ de isoleucina) em água aromatizada ou só água aromatizada, resultando em um total de $85 \mathrm{mg}$ de BCAA/kg de peso corporal. A ingestão foi realizada antes do exercício; durante e imediatamente após o exercício ;15 e 45 minutos na recuperação. A suplementação de BCAA reduziu a expressão de MAFbx mRNA e preveniu o aumento na proteína total MuRF-1 tanto no repouso quanto no exercício. O exercício resistido causou elevação na taxa de MuRF-1 mRNA de proteína total sem influenciar significativamente MAFbx, sugerindo a regulação comum e divergente dessas duas ubiquitinas ligases. A redução dos níveis de fenilalanina e tirosina, assim como a soma de aminoácidos essenciais (exceto BCAA) no músculo em repouso como no exercício durante 3 horas, foi mais pronunciada com BCAA. Estas observações juntamente com o aumento da fosforilação de p70S6k, fornecem suporte adicional de que o BCAA tem efeito anabólico no músculo esquelético, efeito que parece ser semelhante no músculo em repouso e em exercício.

Ferreira et al (2013), utilizaram 3 tipos de suplementos : Carboidrato (CHO) ; CHO+BCAA e placebo. O suplemento de BCAA era composto de 50\% de leucina, 25\% de isoleucina e $25 \%$ de valina e a dose era de $120 \mathrm{mg} / \mathrm{kg}$ de massa corporal. O suplemento de CHO fornecia 1,4g de açúcares (dextrose, frutose e sacarose) em 1,5g. Os participantes consumiram uma dose de $1,5 \mathrm{~g} / \mathrm{kg}$ de massa corporal de CHO. O placebo era uma solução aromatizada. O volume total de ingestão do suplemento foi de $450 \mathrm{ml}$. Sendo que $150 \mathrm{ml}$ foram ingeridos em jejum, no momento da retirada do sangue ; 10 minutos antes do exercício e 5 minutos após o exercício. O estudo demonstrou que nos grupos $\mathrm{CHO}$ e CHO+BCAA, a atividade do IRS-1 é maior do que o placebo e significativamente aumentada em 0,5 e 2 horas pós-exercício.

Em relação aos intermediários de sinalização do IRS-1, Akt e mTOR, aumentaram significativamente a 0,5 e 2 horas pós-exercício e p70S6k a 6 horas pósexercício. Contudo, os aumentos nestes intermediários de sinalização que ocorrem em $\mathrm{CHO}$ e $\mathrm{CHO}+\mathrm{BCAA}$ não foram diferentes daqueles observados com PLC, sugerindo um aumento dependente do exercício resistido, na atividade desses marcadores indicativos de síntese proteica muscular. No estudo verificou-se que a co-ingestão de BCAA e CHO 
não aumentam a indução do exercício resistido e nem aumentam os marcadores de sinalização do músculo esquelético indicativo de síntese proteica muscular, quando comparado com carboidrato sozinho.

Spillane et al (2012) suplementaram os participantes durante 8 semanas, com uma ingestão de 12 cápsulas contendo 9g de BCAA (leucina 4,5g; isoleucina 2,25g; valina 2,25g ) ou 9g de placebo (goma guar). Metade do total da dose diária (6 cápsulas) foi ingerida 30 minutos antes de cada sessão de exercício e a outra metade ( 6 cápsulas ) foi ingerida 30 minutos após cada sessão de exercício. Os suplementos foram ingeridos 4 vezes por semana somente nos dias do exercício. O exercício consistiu de treinamento de resistência em 19 homens sem treinamento (três séries de 8 a 10 repetições), quatro vezes por semana, durante 8 semanas.

Em relação à massa corporal total, nenhum grupo aumentou significativamente com o treinamento e também não houve mudanças significativas na água corporal total. Também não ocorreram alterações com nenhum treinamento ou suplemento na massa gorda ou na massa livre de gordura. A resistência do músculo superior e do músculo inferior aumentaram com o treinamento, mas esses aumentos não foram diferentes entre os grupos. Ambos os grupos mostraram resultados semelhantes, indicando que as melhoras foram devido ao treinamento de resistência. Essas melhoras eram esperadas, porque os participantes não eram treinados. $\mathrm{O}$ estudo concluiu que 8 semanas de treinamento resistido com 9g de BCAA ingeridos 4 vezes por semana, antes e após o exercício, não resultou em efeitos sobre a composição corporal e sobre o desempenho muscular.

O estudo de Howatson et al (2012), analisou o efeito da suplementação de BCAA sobre os marcadores do dano muscular provocado por um esporte específico em voluntários treinados. Foram selecionados 12 homens adultos que realizaram 100 saltos consecutivos, sendo que foram dosadas a creatina quinase, contração máxima voluntária, dor muscular, salto vertical, circunferência da coxa e da panturrilha. Todas as variáveis foram medidas imediatamente antes do exercício e em 24, 48, 72 e 96 horas após o exercício. Os participantes ingeriram 10g, 2 vezes por dia (de manhã e à noite), do suplemento de BCAA ou placebo. O BCAA consistia de leucina, isoleucina e valina $(2: 1: 1)$, o placebo, de adoçante artificial (aspartame), os dois na forma de pó. Cada dose era misturada em 300ml de água. Foi usado o adoçante ao invés de carboidrato, para evitar 
o aumento de insulina e alterar o metabolismo das proteínas. Foram observados efeitos significativos do tempo durante o protocolo. A creatina quinase e a dano muscular foram menores no grupo de BCAA em comparação com o placebo $(\mathrm{p}<0.05)$. A recuperação da contração máxima voluntária foi maior no grupo de BCAA (p< 0.05). Em relação à circunferência da coxa e da panturrilha e salto vertical não foram observadas diferenças entre os grupos. O estudo mostrou que a administração de BCAA antes e após exercício de resistência prejudicial, reduz o índice de dano muscular e acelera a recuperação em adultos treinados. Parece provável que o BCAA proporcionou maior disponibilidade do substrato para melhorar a síntese proteica e ainda a extensão do dano muscular secundário associado ao exercício de resistência extenuante.

\subsection{Performance}

A maior parte da energia requerida para a taxa de contração do músculo esquelético origina-se do metabolismo aeróbio de fontes lipídicas e de hidratos de carbono. A oxidação do BCAA fornece energia dando origem a intermediários do ciclo do ácido tricarboxílico (TCA) por meio de reações anapleróticas (HARGREAVES; SNOW, 2001).

O ciclo do ácido tricarboxílico é importante para a produção de energia que será utilizada para formar ATP, o substrato de energia celular universal (Bowtell et al, 2007).O TCA é diretamente regulado pelo fornecimento de 2 substratos : oxalacetato e acetyl-CoA e seu produto citrato.

Em exercícios de longa duração, o estoque de glicogênio é reduzido e as enzimas responsáveis pela transaminação dos BCAAs têm sua atividade aumentada no músculo esquelético, potencializando a contribuição energética dos aminoácidos durante o exercício (UCHIDA et al, 2008). No estudo de Gualano et al, os participantes foram aleatoriamente designados para BCAA (300mg/kg/dia) ou placebo (maltodextrina) por 3 dias. No segundo dia do estudo, os participantes foram submetidos a um protocolo de depleção de glicogênio induzido por exercício. No terceiro dia, realizaram um teste de exercício exaustivo. Após o empo de exaustão, a relação de troca respiratória, glicose, ácidos graxos livres, cetonas e lactato foram dosados. A suplementação com BCAA promoveu uma maior resistência à fadiga quando comparado com o placebo. Além disso, os participantes suplementados com 
BCAA apresentaram redução na relação de troca respiratória, sugerindo aumento da oxidação lipídica e níveis de glicose plasmática mais elevada durante o teste de esforço exaustivo. É possível que a suplementação de BCAA propicie um aumento de oxalaceto, levando a uma maior oxidação lipídica, devido ao aumento do fluxo do TCA. O estudo mostra que o BCAA parece prevenir a hipoglicemia induzida pelo exercício, articularmente em indivíduos com depleção de glicogênio. Assim, a suplementação de BCAA aumenta a resistência à fadiga e aumenta a oxidação lipídica durante o exercício em indivíduos com depleção de glicogênio. Greer et al, suplementaram 9 homens não treinados com placebo (água, sal , aroma de limão e adoçante), uma bebida com CHO (Gatorade) e BCAA isocalórico (4,8 $\mathrm{g}$ isoleucina, 12,2 $\mathrm{g}$ leucina e 7,3 $\mathrm{g}$ valina). As bebidas foram administradas 5 minutos antes de iniciar o exercício e na marca de 60 minutos. Os indivíduos realizaram 3 sessões de ciclismo de 90 minutos a 55\% de pico de VO2, seguidos por testes de tempo de 15 minutos. Uma grande distância foi percorrida no teste de tempo com CHO em relação ao placebo ( $\mathrm{p}<0.05)$. Não houve diferenças entre BCAA e placebo.

A taxa de percepção de exaustão foi reduzida à marca de 75 minutos e 90 minutos com BCAA quando comparado com placebo. Não foram encontradas diferenças significativas para a interação do teste versus tempo em relação à troca respiratória. Assim, a suplementação de CHO melhora o desempenho em um teste de tempo em comparação com o placebo. A suplementação de BCAA embora eficaz no aumento das concentrações sanguíneas de BCAA, não influenciou o desempenho aeróbio, mas atenuou a taxa de percepção de exaustão em comparação com placebo.

Em outro estudo realizado por Areces et al. (2014), um grupo de corredores foi suplementado com BCAA (5g/dia) na forma de pó (1:0.5:0.5 - leucina, isoleucina, valina) durante 7 dias antes da competição e o outro grupo com um placebo isocalórico. A maratona ocorreu em uma cidade localizada a 655m de altitude (Madri-Espanha), a temperatura variou de 21 a $30^{\circ} \mathrm{C}$. Dentro de 3 minutos após terminar a corrida, os corredores realizaram 2 saltos verticais de contra-movimento e teste de força máxima do punho . A concentração de mioglobina foi determinada nas amostras de urina como um marcador indireto de lesão muscular. Uma escala analógica visual ( $0-10$ pontos $)$ foi usada para avaliar a dor muscular na perna durante a corrida. No grupo BCAA, o ritmo médio de corrida durante a maratona foi semelhante ao grupo controle. A redução no pré 
e pós corrida da potência muscular foi semelhante nos grupos BCAA e controle. Após a corrida, a concentração de mioglobina da urina foi semelhante em ambos os grupos. Não houve diferenças entre os grupos na percepção da dor muscular durante a corrida. 7 dias de suplementação de BCAA não melhorou o desempenho durante a maratona. Além disso, foi ineficaz para evitar a perda de potência muscular, dano muscular ou dor muscular percebida durante uma corrida de maratona.

Em um estudo realizado por Leahy et al. (2013), foi utilizado um suplemento de BCAA comercialmente disponível $(1,22 \mathrm{~g}$ de uma mistura de BCAA, 5,6g dextrose, vitaminas e minerais).O placebo foi formulado para possuir o mesmo sabor e cor do suplemento de teste ( limonada misturada com 5,6g de dextrose em pó). Os indivíduos realizaram um exercício de agachamento para induzir a dor muscular retardada e avaliaram sua dor muscular 24 horas por dia, durante 4 dias após o exercício, enquanto consumiam BCAA ou placebo. Após um período de recuperação de 3 semanas, os indivíduos retornavam e recebiam novamente o tratamento BCAA ou placebo, repetindo o mesmo exercício e o protocolo de classificação da dor muscular retardada durante os 4 dias. O suplemento de BCAA com glicose diminuiu a dor muscular induzida pelo exercício em mulheres relativamente inativas quando comparada com o placebo equivalente. Não foi observado efeito significativo de BCAA com glicose em homens. Não ficou clara a razão exata para os resultados diferentes entre homens e mulheres. Uma explicação possível pode ser pela diferença no peso corporal e massa muscular entre os homens e as mulheres. Os homens tendem a ter um maior peso corporal total e porcentagem de massa muscular magra comparado com as mulheres. Ambos receberam a mesma quantidade de suplemento de BCAA (1220mg/dose). As mulheres receberam mais BCAA por quilograma de peso corporal $(19,5 \mathrm{mg} / \mathrm{kg})$ comparado com os homens ( $16,5 \mathrm{mg} / \mathrm{kg})$. Isto pode explicar o aumento da síntese de proteínas musculares e recuperação da dor muscular retardada no grupo feminino.

Há evidências que com a idade, ocorre declínio da função mitocondrial no músculo esquelético, reduzindo a capacidade aeróbica. Estudos indicam que a taxa máxima de produção de ATP mitocondrial (MAPR) e a atividade das enzimas oxidativas declinam com a idade. O declínio da função mitocondrial está associado com redução da abundância do DNA mitocondrial (mtDNA) (Short et al, 2005 ). 
Segundo o estudo de Tatpat et al. (2010), os BCAAs têm um importante efeito sobre os intermediários do metabolismo que facilitam o aumento da função mitocondrial. Por exemplo, a leucina fornece esqueletos de carbono para formação de acetil-CoA, no ciclo do ácido tricarboxílico, podendo aumentar de forma aguda o fluxo desse ciclo como também da produção de ATP mitocondrial. No estudo, participaram jovens e idosos que receberam uma infusão de BCAA e solução salina. A infusão de BCAA foi administrada $0,13 \mathrm{ml} / \mathrm{kg}$ de massa livre de gordura por hora, durante 30 minutos e reduzida para $0,043 \mathrm{ml} / \mathrm{kg}$ de massa livre de gordura por hora de 30 a 480 minutos. A infusão da solução de salina foi equivalente à da solução de BCAA. A infusão de BCAA foi administrada por 8 horas e a concentração do mesmo na solução utilizada, era de $4 \mathrm{~g}$ em cada $100 \mathrm{ml}$. A quantidade de BCAA administrada no início foi de $2 \mathrm{~g}$ e no final foi de $610 \mathrm{mg}$. Os resultados mostraram que em jovens a MAPR aumentou a resposta à infusão de BCAA, já com a solução salina houve declínio da mesma. A quantidade de mtDNA foi menor nos idosos em relação aos jovens, mas não foi afetada pela infusão de BCAA. O BCAA aumentou a MAPR do músculo esquelético nos jovens em comparação com a solução salina, mas este efeito não foi observado nos participantes idosos indicando que, ao contrário dos jovens, o BCAA não aumenta a função mitocondrial do músculo nos idosos.

Peltier et al. (2011), utilizaram um placebo (ácido cítrico e málico, goma xantana, acesulfame de potássio, sucralose e dióxido de silício) e uma bebida comercial de 1 litro 31,6g maltodextrina; 24,2g dextrose; 12,8g frutose; 4g de BCAA;75mg cafeína; vitaminas minerais). Os participantes beberam $250 \mathrm{ml}$ de cada uma das duas bebidas (bebida comercial e placebo) e durante o teste, ingeriram $250 \mathrm{ml}$ a cada 15 minutos. Foram realizados 2 protocolos. O protocolo 1 consistiu de 2 horas de corrida em esteira. No rotocolo 2,os participantes se exercitaram por 2 horas a $95 \%$ de suas velocidades médias mais baixas registradas no protocolo 1. Comparado com o placebo, a ingestão da bebida comercial aumentou o desempenho na corrida $(\mathrm{p}=0.01)$, a glicemia se manteve e atenuou a fadiga central $(\mathrm{p}=0.04)$ e a taxa de percepção da exaustão $(\mathrm{p}=0,006)$. Este estudo mostrou que a ingestão combinada de CHOs, BCAA e cafeína aumentou o desempenho em cerca de $2 \%$ durante uma corrida em esteira de 2 horas. Entretanto, não foi possível distinguir o efeito de cada um dos componentes da bebida. 


\section{CONCLUSÕES E RECOMENDAÇÕES}

- O presente estudo encontrou 05 estudos com massa muscular, nenhum estudo com gordura corporal e 06 com performance.

- Desses estudos, 05 alcançaram os objetivos propostos, 02 apresentaram desfechos diferentes dos propostos e 04 não apresentaram nenhum tipo de diferença significativa.

- Não foram constatados efeitos colaterais.

- Nossos resultados não permitem recomendar o uso, pois o número de resultados benéficos praticamente se iguala ao de resultados negativos ou a ausência de resultados.

- Há necessidade de mais estudos que avaliem os efeitos fisiológicos dos BCAAs isolados. Visto que os trabalhos diferem muito nos protocolos, dosagens utilizadas, parâmetros e variáveis analisadas. Uma padronização na metodologia poderá garantir resultados mais uniformes e verdadeiros. 


\section{REFERÊNCIAS BIBLIOGRÁFICAS}

ABENUTRI - ASSOCIAÇÃO BRASILEIRA DE PRODUTOS NUTRICIONAIS.

Disponível em:<http//www.abenutri.org >. Acesso em: 06 out 2015.

APRÓ, W.; BLOMSTRAND, E.Influence of supplementation with branchedchain amino acids in combination with resistance exercise on p70S6 kinase phosphorylation in resting and exercising human skeletal muscle. Acta physiologica, 200 (3): 23748, 2010.

ARECES, F.; SALINERO, J.J.; ABIAN-VICEN, J.; GONZÁLEZ-MILLÁN, C.; GALLOSALAZAR, C.; RUIZ-VICENTE, D.; LARA, B.; DEL COSO, J. A 7-day oral supplementation with branched-chain amino acids was ineffective to prevent muscle damage during a marathon. Amino Acids, 46(5):1169-76, 2014 .

BRASIL. Ministério da Saúde. Divisão Nacional de Vigilância Sanitária de Alimentos. Portaria 222, de 24 de março de 1998. Regulamento Técnico para fixação de identidade e qualidade em alimentos para praticantes de atividade física.

BLOMSTRAND, E.; SALTIN, B. BCAA intake affects protein metabolism in muscle after but not during exercise in humans. American Journal of Physiology, 281(2): E365-E374, 2001.

BLOMSTRAND, E.; ELIASSON, J.; KARLSSON, H.K.; KOHNKE, R. Branched-chain amino acids activate key enzymes in protein synthesis after physical exercise. J Nutr.,136, 269S-273-S, 2006.

BORGENVIK, M.; APRÓ, M.B.W.; BLOMSTRAND, E. Intake of branched-chain amino acids influences the levels of MAFbx mRNA and MuRF-1 total protein in resting and exercising human muscle. Am J Physiol Endocrinol Metab, 302: E510-E521, 2012.

BOWTELL, J.L.; MARWOOD,S.; BRUCE,M.;CONSTANTIN-TEODOSIU,D.;GREENHAFF,P.L. Tricarboxylic acid cycle intermediate pool size: functional importance for oxidative metabolism in exercising human skeletal muscle. Sports Med.,37:1071-88, 2007.

BROSNAN, J.T.; BROSNAN M. Branched chain amino acids: enzyme and substrate. J Nutr., 136 (1):2075-2115, 2006.

BRUHAT, A.; CHÉRASSE, Y.; CHAVEROUX, C.; MAURIN, A.; JOUSSE, C.; FAFOUMOUX, P. Amino acids as regulators of gene expression in mammals: Molecular mechanisms . BioFactors, 35: 249-257. 
CHURCHWARD-VENNE, T.; BURD, N.A.; PHILLIPS, S.M. Nutrition regulation of muscle protein synthesis with resistance exercise: strategies to enhance anabolism. Nutr.

Metab.,9(1):40, 2012.

DREYER, H.C.; DRUMMOND, M.J.; PENNINGS, B.; FUJITA, S.;GLYNN, E.L.;CHINKES, D.L.; DHANANI, S.; VOLPI, E. ;RASMUSSEN,B.B. Leucine-enriched essential amino acid and carbohydrate ingestion following resistance exercise enhances mTOR signaling and protein synthesis in human muscle. Am. J. Physiol. Endocrinol. Metab., 294: E392-E400, 2008

EUROMONITOR INTERNATIONAL - Disponível em < http//www.eromonitor.com> Acesso em: 06 out 2015.

FERREIRA, M.P.; Li, R.; COOKE, M.; KREIDER, R.B.; WILLOUGHBY, D.S. Periexercise coingestion of branchedchain amino acids and carbohydrate in men does not preferentially augment resistance exercise induced increases in phosphatidylinositol 3 kinase/protein kinase B mammalian target of rapamycin pathway markers indicative of muscle protein synthesis. Nutrition research , 34 (3): 19-18, 2014.

GREER, B.K.; WHITE, J.P.; ARGUELLO, E.M.; HAYMES, E.M. Branched-chain amino acid supplementation lowers perceived exertion but does not affect performance in untrained males. J Strength Cond Res, 25(2):539-44, 2011.

GUALANO, A.B.; BOZZA, T.; LOPES DE CAMPOS, P.; ROSHEL, H.; DOS SANTOS COSTA, A.; LUIZ MARQUEZI, M.; BENATTI, F.; HERBERT, L. J.A. Branchedchain amino acids supplementation enhances exercise capacity and lipid oxidation during endurance exercise after muscle glycogen depletion. Journal of sports medicine and physical fitness,51 (1):828, 2011.

HALLAK, A. ; FABRINI,S.;, PELUZIO, M.C.G. Avaliação do consumo de suplementos nutricionais em academias da zona sul de Belo Horizonte. Revista Brasileira de Nutrição Esportiva, 1(2): 55-60, 2007.

HARRIS, R.A.; KOBAYASHI, R.; MURAKAMI, T.; SHIMOMURA, Y. Regulation of branched-chain alpha-keto acid dehydrogenase kinase expression in rat liver.J Nutr., 131(3):841S-845S, 2001.

HARGREAVES, M.H.; SNOW, R. Amino acids and endurance exercise. Int. J. Sport. Nutr. Exerc. Metab. 11: 133-145, 2001.

HERMAN, M.A.; SHE, P.; PERONI, O.D.; LYNCH, C.J.; KAHN, B.B. Adipose tissue branched chain amino acid (BCAA) metabolism modulates circulating BCAA levels.J. Biol.Chem., 285(15):11348-56, 2010. 
HIRSCHBRUCH, M.D.; FISBERG, M.; MOCHIZUKI, L.Supplement use amongst young individuals in São Paulo’s fitness centers.Rev. Bras.Med. Esporte, 14 (6), 2008.

HOWATSON, G.; HOAD, M.; GOODALL, S.; TALLENT, J.; BELL, P.G.; FRENCH, D.N. Exercise-induced muscle damage is reduced in resistance-trained males by branched chain amino acids: a randomized, double-blind, placebo controlled study. Journal of the International Society of Sports Nutrition , 9:20, 2012.

HUTSON, S.M.; SWEATT, A.J.; LANOUE, K.F. Branched chain amino acid metabolism: implications for establishing safe intakes.J. Nutr, 135(6):1557S-64S, 2005.

KATSANOS, C.S.; CHINKES, D.L.; PADDON-JONES, D.; ZHANG X.J.; AARSLAND, A.; WOLF, R.R. Whey protein ingestion in elderly results in greater muscle protein accrual than ingestion of its constituent essencial amino acid content. Nutr. Res., 28(10): 651-658, 2008.

KIMBALL, S.R.;JEFFERSON, L.S. Regulation of global and specific mRNA translation by oral administration of branched chain amino acids.Biochem Biophys Res

Commun.,313: 423-7, 2004.

KNECHTLE, B.; MRAZEK, C.; WIRTH, A.; KNECHTLE, P.; RUST, C. A.; SENN, O.;ROSEMANN, T.; IMOBERDORF, R.; BALLMER, P. Branched chain amino acid supplementation during a 100-km ultra-marathon - A randomized controlled trial.J. Nutr.

Sci. Vitaminol., 58, 36-44: 2012.

LEAHY, D.T.; PINTAURO, S.J .Branched-Chain Amino Acid Plus Glucose Supplement Reduces Exercise-Induced Delayed Onset Muscle Soreness in College-Age Females. ISRNNutrition , Article ID921972: 5pages, 2013.

LIBERATI, A.; ALTMAN, D.G.; TETZLAFF, J.; MULROW, C.; GOTZSCHE, P.C.; LOANNIDIS, J.P.; CLARKE, M.; DEVEREAUX P.J.; KLEIJNEN, J.; MOHER, D. The PRISMA statement for reporting systematic reviews and meta-analyses of studies that evaluate health care interventions: explanation and elaboration. J. Clin. Epidemiol., 62(10):1-34, 2009.

MADSEN, K.; MACLEAN, A.D.; KIENS, B.; CHRISTENSEN, D. Effects of glucose plus branched chain amino acids, or placebo on bike performance over $100 \mathrm{~km}$. Journal of Applied Physiology, 81(6): 2644-2650,1996.

MAHAN, L.K.; STUMP, S.E. Alimentos, nutrição e dietoterapia. 10.ed. São Paulo : Roca, 2002.

MONIRUJJAMAN, MD.; FERDOUSE, A. Metabolic and physiological roles of branched chain amino acids. Molecular Biology, 214, article ID 364976, 6 pages, 2014.

MULROW CD. Rationale for systematic reviews. BMJ.,309(6954):597-9, 1994. 
NEWSHOLME, E.A.; BLOMSTRAND, E. Branched chain amino acids and central fadigue. J. Nutr., 136(1): 274S-6S, 2006.

NOGIEC, C.D.; KASIF, S. To supplement or not supplement: a metabolic network framework for human nutritional supplements. Plos one, 8(8):e68751, 2013.

PASIAKOS, S.M. Exercise and amino acid anabolic cell signaling and the regulation of skeletal muscle mass. Nutrients, 4: 740-758, 2012.

PELTIER, S.L.; VINCENT, L.; MILLET, G.Y.; SIRVENT, P.; MORIN, J.B., GUERRAZ, M.; GEYSSANT, A.; LESCUYER, J.F.; FEASSON, L.; MESSONNIER, L. Effects of carbohydrates-BCAAs-caffeine ingestion on performance and neuromuscular function during a 2-h treadmill run: a randomized, double-blind, cross-over placebo-controlled study. Journal of the International Society of Sports Nutrition , 8:22, 2011.

QIN, L.Q.; XUN, P.; BUJNOWSKI, D.; DAVIGLUS, M.L.; VAN HORN, L.;

STAMLER,J.; HE,K. Higher branched-chain amino acid intake is associated with a lower prevalence of being overweight or obese in middle-aged east Asian western adults. J. Nutr., 141(2), 249-54, 2010.

SHIMOMURA, Y.; MURAKAMI, T.; NAKAI, N.; NAGASAKI, M.; HARRIS, R.A. Exercise promotes BCAA catabolism: effects of BCAA supplementation on skeletal muscle during exercise. J. Nutr., 134(6): 1583S-1587S, 2004.

SHORT, K.R.; VITTONE, J.L.; BIGELOW, M.L.; PROCTOR, D.N.; RIZZA, R.A.; COENEN-SCHIMKE, J.M.; NAIR, K.S. Impact of aerobic exercise training on age-related changes in insulin sensitivity and muscle oxidative capacity. Diabetes, 52:1888-1896, 2003.

SOUZA, M.R.; RIBEIRO A.L., Revisão sistemática e meta-análise de estudos de diagnóstico e prognóstico: um tutorial. Arq. Bras. Cardiol., 92(3): 241-251, 2009.

SPILLANE, M.; EMERSON, C; WILLOUGHBY, DS. The effects of 8 weeks of heavy resistance training and branched-chain amino acid supplementation on body composition and muscle performance. Nutr. Health;21(4):263-73, 2012.

TATPATI, L.L.; IRVING, B.A.; TOM, A.; BIGELOW, M.L.; KLAUS, K.; SHORT, K.R.; NAIR, K.S .The effect of branched chain amino acids on skeletal muscle mitochondrial function in young and elderly adults. J Clin Endocrinol Metab;95(2): 894-902, 2010.

THE-COCHRANE-COLLABORATION.Cochrane handbook for systematic reviews of interventions. HOBOKEN, N.J.; WILEY-BLACKWELL; 2008. 
UCHIDA, M.C.; BACURAU, A.V.N.; AOKI, M.S.; BACURAU,R.F.P. Consumo de aminoácidos de cadeia ramificada não afeta o desempenho de endurance. Rev Bras Med Esporte, 14(1):42-45, 2007.

VERHAGEN, A.P.; DE VET, H.C.W.; DE BIE, R.A.; KESSELS, A.G.H.; BOERS, M.; BOUTER, L.M., KNIPSCHILD, P.G. The Delphi List: a criteria list for quality assessment of randomized clinical trials for conducting systematic reviews developed by Delphy Consensus. J. Clin. Epidemiol., 51:1235-41, 1998.

VERHOEVEN, S.; VASCHOONBEEK, K.; VERDIJK, B.L.; KOOPMAN, R.; WODZIG, P.D.; VAN LOON, L.JC. Long-term leucine supplementation does not increase muscle mass or strength in healthy elderly men. Am.J. Clin. Nutr., 89:1468-75, 2009.

WANG, C.; GUO, F. Branched chain amino acids and metabolic regulation. Chinese Science Bulletin.,58(11):1228-1235, 2013.

WOLFE, R.R. Proteins supplements and exercise. Am. J. Clin. Nutr., 72(2): 551S-557S, 2000.

WU, G. Functional amino acids in growth, reproduction, and health. Adv Nutr., 1: 31-37, 2010.

WU, G. Amino acids: metabolism, functions, and nutrition. Amino Acids, 37(1): 1-17, 2009. 